\title{
EL DERECHO CONSTITUCIONAL CUBANO DE 1812 AL 2009: CÁNONES, CICLOS Y MODELOS POLÍTICOS
}

\section{THE CUBAN CONSTITUTIONALISM RIGHT FROM 1812 TO 2009: CANONS, CYCLES, AND POLITICAL MODELS}

\author{
Dr. Carlos Manuel Villabella Armengol. \\ Escuela de Ciencias Sociales y Gobierno del TEC de Monterrey. Mexico \\ Centro de Ciencias Jurídicas de Puebla
}

\begin{abstract}
SUMARIO
I. LIMINAR II. CUBA EN EL CONSTITUCIONALISMO ESPAÑOL DEL SIGLO XIX III. LAS PRIMERAS MANIFESTACIONS CONSTITUCIONALES IV. EL DERECHO CONSTITUCIONAL MAMBÍ V. EL DERECHO CONSTITUCIONAL NACIONAL-BURGUÉS VI EL DERECHO CONSTITUCIONAL REVOLUCIONARIO-SOCIALISTA VII. CONCLUSIONES VIII. BIBLIOGRAFÍA
\end{abstract}

\section{Resumen}

Los estudios de historia constitucional se han realizado, preponderantemente, desde una perspectiva cronológica, en algunos casos, matizados ideológicamente, enfoque que ha propiciado exámenes maniqueos. El presente artículo rompe con esa tesitura, repasa el constitucionalismo nacional diacrónicamente connota los cánones y ciclos constitucionales, expone los modelos de poder político instaurados, y compendian los rasgos de las diferentes fuentes del derecho constitucional.

\begin{abstract}
Abstrac
Cuban Constitutional Law has been studied with a chronological approach that leads to a biased and Manichean examination. This article presents the approach of constitutionalism from a diachronic-synchronic perspective with a holistic methodology that provides productive results by connecting historical sequences with doctrine, as well as connotative canons and constitutional cycles and the models of public political power.
\end{abstract}

Palabras claves: Historia constitucional cubana, constitucionalismo cubano, cánones constitucionales en Cuba, modelos de poder político en Cuba.

Keyword: Cuban Constitutional History, Cuban Constitutionalism, Constitutional Canons in Cuba, Models of Political Power in Cuba

\section{LIMINAR}

La evolución del derecho constitucional cubano se ha expuesto vinculado a los lapsos histórico-políticos por lo que transcurrió la nación: el siglo XIX bajo el dominio colonial español, la primera mitad del siglo XX donde se configura la Republica y el periodo revolucionario-socialista abierto en 1959.

En el primer momento se yuxtapusieron textos heterónomos y autóctonos. Fueron extensivas a la Isla algunas de las constituciones españolas promulgadas 
en esa centuria, se redactaron proyectos constitucionales expresivos de diversas corrientes de pensamiento político criollo y se gestaron las primeras constituciones cubanas en el ámbito de la guerra de independencia.

En el segundo período, etiquetado maniqueamente por un sector de la historiografia como "seudorepública", se promulgaron varias cartas magnas que expresan la conformación del Estado nación y la evolución frágil de la República.

En la tercera etapa, tras una extensa fase de provisionalidad política, la Constitución de 1976 instauró por la Constitución de 1976 un canon jurídicopolítico socialista.

El presente trabajo realiza un metaanálisis del derecho constitucional cubano desde un ámbito histórico-documental y teórico-institucional. Esa perspectiva revela con más certeza que un enfoque meramente diacrónico, las rupturas históricas, los documentos que gestaron cánones ${ }^{1}$ y abrieron ciclos constitucionales, $^{2}$ los modelos de poder politico público ${ }^{3}$ que se institucionalizaron, y las caracteriticas de las fuentes que conforman el derecho constitucional cubano. El estudio emplea los métodos histórico-lógico, análisis de contenido y hermenéutico. ${ }^{4}$

\section{CUBA EN EL CONSTITUCIONALISMO ESPAÑOL DEL SIGLO XIX}

En el siglo XIX se promulgaron en España constituciones en los años 1812, 1834, 1837, 1845, 1869 y 1876. De éstas, fueron relevantes para la Isla las de 1812 y 1837. Asimismo, se emitió una ley especial para Cuba y Puerto Rico en 1897.

La Constitución de Cádiz emergió de las Cortes Generales y Extraordinarias que comenzaron a sesionar en León el 24 de septiembre de 1810 y continuaron en Cádiz, firmándose el 19 de marzo de 1812. En la isla se eligieron como diputados propietarios a Juan Bernando O'Gavan y Andrés de Jáuregui, pero tomaron posesión los suplentes Juan Clemente Nuñez del Castillo, Marqués de San Felipe y Santiago; y Joaquín Santa Cruz, Coronel agregado del Regimiento de

1 Se identifica como canon constitucional al texto que impone pautas novedosas, renueva instituciones y conceptos, y genera claves para la interpretación y aplicación de las normas. BELKIN, Jack M. Y LEVINSON, Sanford, "Los cánones en el derecho constitucional”, en Miguel Carbonell y Leonardo García Jaramillo (eds.), El canon constitucional del neoconstitucionalismo, Instituto de Investigaciones Jurídicas-UNAM, Editorial Trotta, México, 2010, p. 35.

2 Un ciclo constitucional se produce cuando otros textos siguen el patrón de una Constitución anterior. VergotTini, Giuseppe de, Derecho Constitucional Comparado, Espasa-Calpe, Madrid, 1983, p. 203.

${ }^{3}$ En este estudio la categoría modelo de poder politico público identifica la fisonomía de éste a partir de la dinámica estructural-funcional de los órganos supremos de poder, cuestión que sintetiza con precisión el concepto forma de gobierno. VERGoTTINI, Giuseppe de, Derecho Constitucional Comparado, ob. cit., FiX-ZAmudio, Héctor y VAlencia CARMona, Salvador, Derecho Constitucional Mexicano y Comprado, UNAM, Editorial Porrúa, México, 2001. BISCARETTI DI RUFFIA, Paolo, Introducción al Derecho Constitucional Comparado, 2da edición, Fondo de Cultura Económica, México, 2000.

4 Esta linea de análisis la he seguido en otros trabajos: Villabella Armengol, Carlos Manuel: Historia constitucional y poder politico en Cuba, Editorial Ácana, Camagüey, 2009. "De Guáimaro a La Habana: historiografia del poder politico en Cuba desde una perspectiva constitucional", Revista Cubana de Derecho, Núm. 32, Julio-Diciembre 2009, pp. 5-32. 
Milicias Disciplinarias de Infantería. Jáuregui asumió la diputación en mayo de 1811 y O'Gavan en marzo de 1812.5

Fue una carta liminar del pensamiento revolucionario decimonónico, extensa (384 artículos), con los siguientes rasgos sobresalientes: tono reglamentista y programático en algunos contenidos; consagró los principios del liberalismo político (soberanía nacional, tripartición de poderes, igualdad y libertad de los ciudadanos, representación no estamental, independencia del poder judicial, garantias procesales a la libertad, mandato representativo, responsabilidad ministerial); estableció una monarquía limitada, organizada sobre el principio de separación de poderes entre el Rey, las Cortes (unicameral, integrada por los diputados de ambos hemisferios electos sobre criterios de proporcionalidad) y los tribunales; instituyó el Consejo de Estado como órgano consultivo del monarca e integrado por hombres ilustres; reguló las atribuciones de los ayuntamientos y diputaciones; refrendó derechos y libertades individuales y el principio de igualdad ante la ley; esbozó un sistema de defensa política de los contenidos al señalar que todo español tenía derecho a reclamar su inobservancia y que la diputación permanente velaba por su cumplimiento.

Reconoció también que la nación era la reunión de los españoles de ambos hemisferios, aspecto que había sido plasmado por las Cortes en los decretos de 15 de octubre de 1810 y 9 de febrero de 1811; empero, el enunciado no se materializó. La idea de nación, el concepto de soberanía y el principio de igualdad, fueron entendidos desde diferentes ángulos por los diputados americanos y los liberales de la península. ${ }^{6}$ En ese punto, estos últimos fueron poco consecuentes con su ideario revolucionario: ${ }^{7}$

(...) las reivindicaciones ultramarinas caían en saco roto y serian sistemáticamente combatidas y negadas en su mayoría por los liberales peninsulares con una actitud imprudente (...) La obstinación de los liberales de la Metrópoli en creer que la promulgación de la Constitución doceañista sería la panacea para solucionar todos los males que aquejaban a las provincias españolas de Ultramar, resultaria contraproducente al fin y al cabo $(\ldots) .^{8}$

A su regreso a España Fernando VII, "El Deseado", la derogó mediante el Real Decreto del 4 de mayo de 1814 que dispuso que debía considerarse "como si no hubiesen pasado jamás tales actos y se quitasen de en medio del tiempo, y sin

\footnotetext{
5 RiEU-Millan, Marie Laurie, Los diputados americanos en las Cortes de Cádiz (igualdad e independencia), Biblioteca de Historia de América, Consejo Superior de Investigaciones Científica, Madrid, 1990, pp. 3 y ss.

6 Suanzes-Carpagena, Joaquín Varela, La Teoría del Estado en los origenes del constitucionalismo hispano (Las Cortes de Cádiz), Centro de Estudios Constitucionales, Madrid, 1983, pp. 245 y ss.

7 PÉrez Guilhou, Dardo. La opinión pública española y las cortes de Cádiz frente a la emancipación hispanoamericana. 1808-1814, Academia Nacional de la Historia, Buenos Aires, 1981 , p. 59.

8 FRANCO PÉREZ; Antonio-Filiú, Cuba en los orígenes del constitucionalismo español: la alternativa descentralizadora (1801-1837), Fundación Manual Gimenez Abad de Estudios Parlamentarios y del Estado Autonómico, Zaragoza, 2011, pp. 112-113.
} 
obligación en mis pueblos y súbditos de cualquier clase y condición a cumplirlos y a guardarlos". 9

Rigió nuevamente entre marzo de 1820 y abril de 1823. El detonante de la proclamación fue el levantamiento del Coronel Rafael del Riego en Sevilla el 1 de enero de 1820, conato al que se sumaron otras guarniciones que obligaron al rey Fernando VII a emitir el 10 de marzo un decreto con el anuncio. Así, inició el Trienio Liberal en el que regresaron al gobierno los reformistas. La reinstauración se conoció en La Habana por la tripulación del bergantín Monserrate, ${ }^{10} \mathrm{y}$, aunque el Capitán General Juan Manuel de Cajigal intentó retardar su difusión, los regimientos Cataluña y Málaga obligaron a la publicación de la noticia. El Real Decreto de 24 de abril de 1820 estipuló que se divulgara los domingos en la Iglesia y que los maestros de primeras letras la comentaran, y la Real Orden de 12 de enero de 1821 estableció su enseñanza. La invasión a España de los "Cien Mil Hijos de San Luis" el 1ro de octubre de 1823, auspiciada por la Santa Alianza en el Congreso de Verona, cerró este segundo período.

Tuvo un tercer momento de vigencia entre agosto de 1836 y junio de 1837 . En 1836 se produjeron levantamientos de sectores progresistas del Ejército, el más importante, el Motín de la Granja que provocó que la Reina Regente María Cristina de Borbón, recibiera una representación de los militares y accediera el 13 de agosto a restaurarla. En esta ocasión, la noticia llegó a Santiago de Cuba el 29 de septiembre de 1936 mediante los navegantes del bergantín Guadalupe. El Gobernador y Comandante General de Oriente Manuel Lorenzo, organizó su juramento y despachó la información a La Habana, pero el Capitán General Miguel Tacón exclamó que "si se la mandaban a jurar, estableceria mil horcas para los que desmanden y alboroten, y evitar así cualquier consecuencia". ${ }^{11} \mathrm{El}$ Real Decreto del 19 de agosto aclaró que se aplicaria solamente en la península e islas adyacentes, y que las provincias de ultramar quedaban a la espera de lo que dispusieran las Cortes. Desde la capital, se adoptaron medidas militares contra Santiago de Cuba y se consideró insubordinado al Comandante de la plaza. Éste dimitió y fue sometido a juicio de residencia.

La Constitución gaditana fue transcendente para Latinoamérica porque introdujo las ideas liberales. ${ }^{12}$ En Cuba, el impacto pudo percibirse en el ámbito jurídico-institucional e ideológico. ${ }^{13}$

9 SÁNCHEZ-ARCILlA BERNAL, José, Historia de las instituciones politico-administrativas contemporáneas (1808-1975), Dykinson, Madrid, 1994, p. 28.

10 Noticias de las principales ocurrencias acaecidas en La Habana el día 15 de abril de 1820 y siguientes remitidas por el Intendente de Ejército al Secretario del Estado y el Despacho, Archivo Nacional de Cuba, Fondo del Gobierno Civil.

11 Monte, C. M. Colección Cubana, 1-8, 28 de septiembre de 1836, citado por PORTUONDO ZuñIgA, Olga, Cuba. Constitución y liberalismo (1808-1841), Editorial Oriente, Santiago de Cuba, vol. II, 2008, p. 15.

12 Ver, entre otros: FERnÁNDEZ SARASOlA, Ignacio, "La Constitución de 1812 y su proyección europea, e iberoamericana”, Fundamentos, Cuadernos monográficos de teoría del Estado, derecho público e historia constitucional, Núm. 2, 2000, pp. 359-457. MARTIRÉ, Eduardo, Proyección del liberalismo gaditano en los paises de América, Las Cortes de Castilla y León (1188-1988), Cortes de Castilla y León, Valladolid, 1990, pp. 663-703. CRUZ Villalón, Pedro; Lorente SARIÑEnA, Marta; et. al., Los orígenes del constitucionalismo liberal en España e Iberoamérica: Un estudio comparado, Junta de Andalucía/Consejería de Cultura y Medio Ambiente, Sevilla, 1994. 
Inmediatamente se produjo la adecuación institucional y jurídica del ordenamiento de la Isla, verbigracia: el país quedó dividido en tres departamentos con diputaciones provinciales; se separó la administración de justicia civil de la militar; fue eliminado el tribunal inquisitorial; se reordenaron los municipios; y reconocieron derechos, entre ellos, la libertad de imprenta. De estos aspectos, merecen comentarse los dos últimos por su trascendencia.

El municipalismo normado por las Ordenanzas de Cáceres de 1573 fue renovado, se crearon órganos locales en poblados que no lo tenían, instituyéndose la elegibilidad y renovación de los cargos públicos, se legitimó el ayuntamiento como el modelo de gobierno local y estipuló que los vecinos pudieran acudir a sus sesiones, también, se regularon las competencias locales configuradoras de un pouvoir municipal. Carrera Justiz reconoció que: "la normalidad, rayana en petrificación, con que venían desenvolviéndose desde el Siglo XVI las municipalidades cubanas, recibió el más hondo de los sacudimientos y hubo un renacimiento liberal del espíritu romano-español del Siglo XV en que las municipalidades eran casi todo en la vida oficial."14

La libertad de imprenta decretada por las Cortes el 12 de noviembre de 1810 y refrendada en el artículo 131 de la Constitución, se implementó en la Isla en 1811 , constituyendo una de las medidas de mayor repercusión porque posibilitó la libre circulación de ideas, permitiendo, como sostiene Portuondo Zuñiga, "expresarse con osadia hasta entonces contenida." 15 Se crearon imprentas, editaron periódicos y publicaron textos. En 1812 se imprimieron 95 libros,

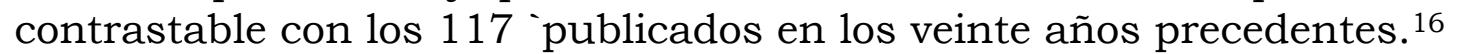

La difusión de liberalismo y el libre debate influyó a su vez en que la polémica sobre los temas nacionales se ideologizara. Como reconoce Reinaldo Suarez: "la mayor repercusión (de Cádiz) radica en lo ideológico, en la siembra hecha en la cultura política de la colonia. Catalizó un adelanto significativo en la conformación de nuestra nacionalidad, al propiciar el debate de ideas y visiones y los necesarios procesos de tipificación y diferenciación de identidades (...) incluido el estamento de "pardos y morenos". ${ }^{17}$

De manera mediata, el documento influyó también en las leyes fundamentales mambisas que se redactaron en la segunda mitad de la centuria, las que asumieron algunos de sus principios y normas; exempli gratia: noción de soberania nacional, principio de tripartición de poderes, independencia del poder judicial, separación de la jurisdicción civil y militar, derecho de libertad, garantías

13 Para un análisis de la influencia de la Constitución de Cádiz en Cuba: MATILlA CORREA, Andry y Massó Garrote, Marcos Francisco (Coords.), De Cádiz (1812-2012) a La Habana, Estudios con motivo del bicentenario de la Constitución española de 1812, ONBC, Unión Nacional de Juristas de Cuba, Universidad de la Habana, Universidad de Castilla-La Mancha, La Habana, 2012.

14 CARrera Jústiz, Francisco, Introducción a la historia de las instituciones locales de Cuba, Librería e Imprenta La Moderna Poesía, La Habana, vol. II, 1905, p. 169.

15 Portuondo Zuñiga, Olga, Cuba. Constitución y liberalismo (1808-1841), vol. I, ob. cit., p. 101.

16 Bachiller y Morales, Antonio, Apuntes para la historia de las letras y de la instrucción pública en la isla de Cuba, Cultural, S. A., La Habana, vol. III, 1937, pp. 243-457.

17 Suarez Suarez, Reinaldo, "Repercusiones de la Constitución de Cádiz en Cuba (1812-1814)”, en Hitos constitucionales del siglo XIX cubano, en Carlos Villabella Armengol, Hitos constitucionales del siglo XIX cubano, Editorial Ácana, Camagüey, 2011, p. 48. 
procesales de la libertad, descripción del territorio como elemento físico del Estado, regulación de la ciudadanía, principio de responsabilidad de los representantes, deber de participar en la defensa de la patria y pagar impuestos.

El Estatuto Real de 1834 promulgado por la reina regente María Cristina en el contexto de la Primera Guerra Carlista, ${ }^{18}$ respondió a una transacción entre la nobleza, el clero y la burguesía conservadora. Como indica Tomás y Valiente, constituyó "la partida de nacimiento del moderantismo español en su versión más conservadora, menos liberal, (postulando) fórmulas conciliadoras entre principios del Antiguo Régimen". ${ }^{19}$ Sólo reguló la composición y funcionamiento de la Corte.

La Constitución de 1837 obedeció al consenso entre progresistas y moderados de alejarse de la normativa de 1812, concibiendo una ley que, al decir de Joaquín Varela, fue "doctrinalmente simbiótica, sincrética y transaccional".20 Marcó un cambio en el tratamiento de los territorios de ultramar, lo que patentizo en el artículo adicional segundo al señalar que las provincias de ultramar serían gobernadas por leyes especiales. Así, se mutó el modelo inclusivo e igualitario aprobado en Cádiz, por otro excluyente y diferenciador

El reconocimiento de la particularidad de la Isla habia sido una demanda del patriciado cubano, lo que se acompañaba del reclamo de autonomía. En esta ocasión, el argumento fue utilizado por la península para sostener el tratamiento especial de la Isla, aduciéndose que, la distancia, la disimilitud de la población y los problemas de representación que ello acarreaba, justificaban tal decisión.

Fueron elegidos en virtud del Real Decreto de convocatoria a Cortes de 21 de agosto de 1836, Francisco de Armas por el distrito Puerto Príncipe, Nicolás Manuel Escobedo y Juan Montalvo y Castillo por la Habana, y José Antonio Saco por el distrito de Santiago de Cuba. Como diputados suplentes, Matías de Mesa, Pablo Bory y Gabriel Suarez del Villar. Presentaron sus poderes, Saco el 6 de enero de 1837 y de Armas el día 8,21 pero no los dejaron tomar posesión de sus cargos. La exclusión fue reclamada por Saco y otros diputados en un oficio que enviaron al presidente de la comisión de poderes. En otro informe expusieron las razones que asistían a las provincias para ser regidas por las leyes que la peninsula:

“ (...) desde la formación de las leyes de Indias todas las posesiones americanas fueron declaradas parte integrante de la monarquía, y por lo mismo, con derecho a ser representadas en los Congresos nacionales (...) porque siendo las Cortes, según el artículo 27 del Código de Cádiz, la reunión de todos los diputados de la Nación y formando Cuba parte de ella, es claro que excluyéndola de la representación nacional se quebranta la ley que todavía nos rige (...) Porque teniendo las provincias de Ultramar necesidades particulares absolutamente desconocidas (...) es indispensable la intervención de los de aquellos países para que puedan exponerlas (...)

18 PRo RuIZ, Juan, El Estatuto Real y la Constitución de 1837, IUSTEL, Madrid, 2010.

19 Tomás y VAliente, Francisco. Manual de Historia del Derecho Español, Editorial Tecnos, Madrid, 2005, p. 443.

20 VAREla SuANZEZ-CARPEGnA, Joaquín, "La Constitución española de 1837: una Constitución transaccional”, Revista de Derecho Político, Núm. 20, invierno, 1983-1984, pp. 95-106.

${ }^{21}$ Portuondo Zuñiga, Olga, Cuba. Constitución y liberalismo (1808-1841), vol. I, ob. cit. p. 266. 
no sólo es justo, son además también necesario, que todos y cada uno de los miembros de la gran familia española vuelvan a congregarse para que las condiciones de esta nueva alianza queden marcadas con el sello de la justicia y la aprobación nacional (...)".22

Las comisiones de Ultramar y de Constitución emitieron un dictamen el 10 de febrero que ratificó la decisión: "las provincias ultramarinas de América y Asia, serán regidas y administradas por leyes especiales y análogas a su respectiva situación y circunstancias, y propias para hacer su felicidad, y en consecuencia no tomarán asiento en las Cortes actuales, los Diputados por las expresadas provincias". ${ }^{23}$ De esa manera, se ratificaba el estatus colonial de los territorios ultramarinos. Como señala Franco Pérez: “(..) ese proceso de constitucionalización discurrió a través de actuaciones parlamentarias sinuosas (...) que obedecieron a una razón de Estado -inicialmente encubierta- (...) reforzar la relación colonial entre la Metrópoli peninsular y sus posiciones de Ultramar, toda vez que se pretendía que estas últimas financiasen tan costoso proceso (...)" 24

La Constitución de 1869, rectificó lo anterior y asentó las bases de un régimen asimilista en el artículo 108 del Título X "De las provincias de ultramar": "Las Cortes reformarán el sistema actual de gobierno de las provincias de Ultramar, cuando hayan tomado asiento los Diputados de Cuba o Puerto Rico, para hacer extensivos a las mismas, con las modificaciones que se creyeren necesarias, los derechos consignados en la Constitución".

La carta suprema de 1876 redactada al culminar la Tercera Guerra Carlista (1872-1876), consecuencia del derrumbe de la I República y la restauración de la dinastía borbónica con Alfonso XII en 1874, continuo la línea moderada de la ley fundamental de 1845 y retomó el principio de prevalencia monárquica. Asentó las bases para un régimen descentralizador al escribir en el artículo 89 que las provincias de ultramar serian gobernadas por leyes especiales, añadiendo en el artículo transitorio, que se determinaría cuándo y en qué forma serian elegidos los representantes a las Cortes. Fueron seleccionados a tenor del Decreto de 1ro de marzo de 1878 Rafael Montoro, Miguel Figueroa y Rafael Hernández de Castro. ${ }^{25}$

La política diferenciadora hacia Cuba se concretó finalmente con la Constitución Autonómica de 1897 para Cuba y Puerto Rico, promulgada por el Real Decreto de 25 de noviembre de 1897. Rigió del primero de mayo de 1898 hasta el primero de enero de 1899. En setenta artículos, reguló la organización del poder, conformada por el Parlamento Insular bicameral (Consejo de

22 Lazcano y Masón, Andrés M., Las Constituciones de Cuba, Ediciones Cultura Hispánica, Madrid, 1952, pp. 18-19.

23 "Dictamen de las Comisiones reunidas de Ultramar y Constitución,10 de febrero de 1837, proponiendo que las provincias ultramarinas de América y Asia sean regidas y administradas por leyes especiales", Apéndice al DSC, No. 112, de 12 de febrero de 1937, p. 1493.

24 FrANCO PÉREZ; Antonio-Filiú, Cuba en los orígenes del constitucionalismo español: la alternativa descentralizadora (1801-1837), ob. cit., p.761.

25 Guerra y SÁnchez, Ramiro; Pérez CABrera, José; Remos, Juan J.; SANTovenia, Emeterio S., Historia de la Nación Cubana, vol. VII, Editorial Historia de la Nación Cubana, S. A., La Habana, 1952, pp. 78-79. 
Administración y la Cámara de Representantes) y el Gobernador General. El primero, tenía facultad para legislar sobre los asuntos locales mediante estatutos y pronunciarse en contenidos que no hubiesen sido reservados al gobierno central. El segundo, se desempeñaba como delegado directo del rey y jefe del poder ejecutivo colonial. Ordenó también, el poder local en manos del ayuntamiento y la diputación provincial. Junto a esta norma, estuvo vigente el título primero de la ley fundamental de 1876 referido a los derechos y se emitieron varios decretos para instaurar el régimen autonómico.

La aspiración descentralizadora había evolucionado en la Isla con diferentes matices desde inicios del siglo como se expondrá ut infra, y la metrópoli la había enarbolado oportunistamente en momentos de crisis del sistema colonial, sin concretar en realidad cambió en su política centralista. En 1821 se efectuó una reforma al texto de 1812 que abría las puertas a un modelo federal que posibilitaba la representación de los territorios de ultramar. ${ }^{26}$ En 1837, la exclusión de los diputados a Cortes y el anuncio de que se emitirian leyes especiales renovaron las expectativas en tal sentido, encontrando cauce en la Junta de Notables conformada por la Real Orden de 28 de julio de 1837 concebida para asesorar la redacción de las leyes especiales, empero, está languideció sin resultados. ${ }^{27}$ En 1878 la frustración por la culminación de la Guerra de los Diez años y la promesa de España de efectuar cambios en la organización política, realzó las ansias descentralizadoras, estructurándose la élite que fundaría el Partido Liberal Autonomista en 1881.28

En los años siguientes se corporizaron propuestas de gobierno autonómico en la península. En 1892 el ministro de Ultramar Antonio Maura planteó un proyecto que tenía como eje la creación de una Diputación provincial con atribuciones administrativas locales y un Gobernador general con facultades ejecutivas. En 1895, el siguiente ministro de Ultramar Buenaventura Abarzuza, presentó otro plan que diluía las funciones de la Diputación provincial (elemento de mayor rechazo de la fórmula anterior) en el Consejo de Administración y la Junta de Autoridades, reconocía al Gobernador como jefe superior de la administración civil, y creaba seis diputaciones para regular la actividad municipal. Este texto se aprobó, pero no entró en vigor por el inicio de la guerra.

26 Fernández Sarazola, Ignacio, Proyectos constitucionales de España (1786-1824), Centro de Estudios Político Constitucionales, Madrid, 2004, pp. 421-431. Sobre las fórmulas que se idearon para el gobierno de los territorios de ultramar, ver: SÁNCHEZ ANDRÉs, Agustín, "La búsqueda de un nuevo modelo de relaciones con los territorios ultramarinos durante el Trienio Liberal (1820-1823)", Revista de Indias, Núm. 210, 1997, pp. 451-474.

27 Infiesta y Pages, Ramón, Derecho Constitucional, 2da ed., Editorial LEX, La Habana, 1954, pp. 116-117.

28 Alonso Romero, María Paz, “Cuba, provincia asimilada: 1878-1898”, en Derecho y Administración Pública en las Indias hispánicas (Actas del XII Congreso Internacional de Historia del Derecho Indiano), Ediciones Universidad de Castilla- La Mancha, Cuenca, vol. I, 2002, pp. 75-99.

Alonso Romero, María Paz, Cuba en la España liberal (1837-1898) Génesis y desarrollo del régimen autonómico, Centro de Estudio Político Constitucionales, Madrid, 2002. BIZCARRONDO, Marta y ElorzA, Antonio, Cuba/España. El dilema autonomista, 1878-1898, Editorial Colibrí, Madrid, 2001. GARCía MorA, Luis Miguel, "La fuerza de la palabra. El autonomismo en Cuba en el último tercio del siglo XIX”, Revista de Indias, vol. LXI, Núm. 223, pp. 715-748. ToRRE, Mildred de la, El autonomismo en Cuba, 1878-1898, Editorial Ciencias Sociales, La Habana, 1997. 
En esa tesitura, es patente que la carta de 1897 y el modelo de gobierno autonómico que implementó por unos meses, constituyó una solución tardía, desesperada e inútil de resolver el problema de la Isla. Como esboza con precisión el citado Franco Pérez:

La descentralización colonial fue enfocada de forma diferente desde un lado y otro del Atlántico. Desde la Isla el proyecto descentralizador fue diseñado como estrategia político-jurídica que tenía como fin que España le otorgase a Cuba potestad legislativa para que, preservando la soberanía española sobre el territorio insular, los cubanos pudieran construir un espacio político propio. Desde la península la descentralización colonial siempre fue vista con reticencia por conservadores y liberales, y cuando se utilizó por unos y otros se hizo como medida in extremis, esto es, como táctica complementaria de una estrategia de contención que perseguía detener los efectos del nacionalismo independentista. ${ }^{29}$

\section{LAS PRIMERAS MANIFESTACIONES CONSTITUCIONALES}

En la primera mitad del siglo XIX eclosionaron en la Isla diversas contradicciones sociales, económicas y políticas; derivadas de la forma de gobierno centralizada, el proteccionismo económico, el desarrollo de un modo de producción esclavista con elementos pre-capitalista y la exclusión de los criollos de la vida politica nacional. En ese tejido, se gestaron diferentes corrientes de pensamiento político que proponian distintas alternativas a la solución de los problemas de la Isla: el reformismo, el anexionismo y el independentismo.

Algunos autores, establecen periodizaciones de estas tendencias, ${ }^{30}$ otros, aprecian la existencia de un pensamiento liberal-reformista que evolucionó y se manifestó de diferentes maneras: el liberalismo conservador de la burguesía comercial peninsular cuyos intereses coinciden, por momentos, con los de la sacarocracia cubana; el liberalismo reformista de los sectores no dominantes de la mediana burguesía; y el liberalismo radical de la pequeña burguesía y los jóvenes ilustrados. ${ }^{31}$

En ese contexto de ideas y contradicciones socioclasista, se pensó a Cuba y se gestó la noción de patria. Como asevera Torres Cuevas:

El siglo XIX cubano fue un siglo fundacional. En él surgió la cultura de pensar, conocer y hacer a Cuba (...) En la confrontación de ideas, una nueva cualidad sociocultural comenzó a definirse (...) había que crear a Cuba desde sus propios componentes hasta entonces desarticulados y hostiles entre sí (...) A este proceso Fernando Ortiz lo llamó transculturación, pero ello constituyó sólo la primera fase. La segunda, el surgimiento de una cualidad cultural

29 FRANCO PÉREZ, Antonio-Filiu, "Cuba y el orden jurídico español del siglo XIX: La descentralización colonial como estrategia y táctica jurídico-politica (1837-1898)", Revista Historia constitucional, Núm. 5, 2002, pp. 313-324.

30 AguIRre, Sergio, Nacionalidad y nación en el siglo XIX cubano, Ciencias Sociales, La Habana, 1990 , p. 7.

31 BARCiA, María del Carmen; GARcía, Gloria; Torres Cueva, Eduardo, Historia de la colonia, evolución socioeconómica y formación nacional, desde los orígenes hasta 1867, Editora Política, La Habana, 1994, p. 337. 
nueva lo denominó culturación (...) se fue conformando lo cubano que transita del criollismo -mezcla incierta de elementos- a la cubanidad. ${ }^{32}$

Aristas de ese ideario político tomaron cuerpo en informes, memorandos, instrucciones y proyectos constitucionales, algunos de poca factura jurídica, redactados por conspicuos exponentes del patriciado cubano. La historiografia nacional cita, mayoritariamente, los pliegos de Francisco de Arango y Parreño, José Agustín Caballero y Rodríguez de la Barrera, Joaquín Infante Infante, Félix Varela y Morales, Gabriel Claudio Zequeira, Narciso López de Urriola y la Sociedad Ave María. 33

Se señala que los escritos de Francisco de Arango y Parreño y José Agustín Caballero, son asimilistas; el de Joaquín Infante, separatista; el de Gabriel Claudio Zequeira y Félix Varela, autonomistas; y los de Narciso López y la Sociedad Ave Maria, anexionistas. ${ }^{34}$ Otra catalogación acota que los documentos de Caballero, Zequeira y Varela son autonomistas; y los de Infante, López y la Sociedad Ave María separatistas. ${ }^{35}$ Una tercera propuesta sostiene que el informe de Arango es asimilista, el de Caballero y Zequeira autonomista, el de Varela reformista y el de López anexionista. ${ }^{36}$

Francisco de Arango y Parreño, Director de la Sociedad Patriótica de La Habana, síndico perpetuo del Real Consulado de Agricultura y Comercio, Oidor de la Audiencia de Santo Domingo y Ministro del Supremo Consejo de Indias; no elaboró un proyecto constitucional como tal, sino que participo en una iniciativa presentada en julio de 1808 al Ayuntamiento de La Habana para conformar una Junta de Gobierno, similar a la que se había organizado en la península. El texto fue redactado por Agustín de Ibarra a instancia del Capitán general Salvador José Moro y Salazar, Marqués de Someruelos, y un grupo de representantes destacados de la sociedad habanera. ${ }^{37}$ Se transcribió en 1821 por Arango bajo el título "Representación de personas notables de La Habana al Ayuntamiento, el 26 de julio de 1808, para que se organizase una Junta Superior de Gobierno con autoridad igual a la de las establecidas en la Península".

32 Torres-Cuevas, Eduardo, Historia del pensamiento cubano, vol. I, Editorial Ciencias Sociales, La Habana, 2006, pp. 9 y ss.

33 Fue fundada en Nueva York por los seguidores de Narciso López tras su muerte y presidida José Elías Hernández, asumió el proyecto de López e incorporó la propuesta de la abolición de la esclavitud.

34 CARreras, Julio Ángel, Historia del Estado y el Derecho en Cuba, Editorial Pueblo y Educación, La Habana, 1982. p. 151 y ss. VEGA VEGA, Juan, Derecho constitucional revolucionario en Cuba, Editorial Pueblo y Educación, La Habana, 1982, p. 30 y ss.

35 Bernal Gómez, Beatriz, Constituciones Iberoamericanas: Cuba, pp. 2 y ss. InfIESTA, Ramón, Derecho Constitucional, ob. Cit., 171 y ss.

36 Fernández Bulté, Julio, Historia del Estado y el Derecho en Cuba, Editorial Félix Varela, La Habana, 2005, pp. 66 y ss.

37 Entre los firmantes se encontraban: Francisco de Arango y Parreño; José de Ilincheta, asesor del Capitán General; Pedro Pablo de O`Reilly y Arredondo, Comandante del Regimiento de La Habana y alguacil mayor del Cabildo; Tomás de la Cruz Muñoz, síndico procurador del Ayuntamiento; José María Xenes, regidor; Andrés de Jáuregui, alcalde ordinario. En total, lo suscribieron 73 personas de la elite militar, eclesiástica y económica habanera; de ellos, 46 y 27 criollos.37 (VÁZquez Cienfuegos, Sigfrido y AMOREs CARredano, Juan B., "En legitima representación: los firmantes del fallido proyecto de Junta de La Habana en 1808", Anuario de Estudios Americanos, vol. 68, Núm. 1, 2011, pp. 105-139). 
Se presentó al Ayuntamiento el 26 de julio y al día siguiente fue retirado ante el rechazo que suscitó en varios sectores. El memorándum reconocía la autoridad de Fernando VII, pero destacaba que para "mantener la unión y la paz interior", era necesario "el establecimiento de una Junta Superior de Gobierno que, revestida de igual autoridad a las demás de la península de España, cuide y provea todo lo concerniente a nuestra existencia politica y civil, bajo del suave dominio de nuestro adorado monarca, a quien debe de representar". ${ }^{38} \mathrm{El}$ órgano se integraría por representantes de la oligarquía local, reconocidos en el documento como "notables miembros de la sociedad". ${ }^{39}$ Durante su misión de diputado Cortes en 1813, Arango y Parreño trató de impulsar la iniciativa.

El proyecto de José Agustín Caballero y Rodríguez de la Barrera (1811) denominado "Exposición a las Cortes españolas", fue entregado al diputado Andrés de Jáuregui para que se tuviera en cuenta en los debates de "La Pepa".40 Fue documento primigenio del pensamiento reformista-descentralizador y sintetiza las aspiraciones de la oligarquía criolla: convicción monárquica ("el gobierno que nos conviene es el Monárquico hereditario y limitado"), descentralización ("no es posible, que a la distancia en que está el Nuevo Mundo del antiguo, pueda Gobierno ninguno situado en Europa, gobernar a los pueblos con conocimiento de sus necesidades locales") ${ }^{41}$ autogobierno e incorporación de los criollos en la vida política. De esa manera, trasluce la contradicción en la que se encuentra entrampada esta clase: la patria es una a ambos lados de océano; pero a su vez, existen diferencias entre la "Madre Patria" y la "España ultramarina". 42

Como plantea el aludido Franco Pérez: "Inaugura la dimensión jurídica (...) del protoparticularismo cubano, si por tal se entiende la etapa histórica que se corresponde con las primigenias reivindicaciones identitarias cubanas (...) que reclamaba una reforma del modelo de política colonial para, (y) con ello, favorecer que a los criollos se les permitiera la autogestión de sus propios intereses. ${ }^{43}$

El proyecto de Gabriel Claudio de Zequeira, Teniente de Fragata de la Armada Española, Comandante del batallón primero de milicias nacionales de extramuros de la ciudad de La Habana y Regidor del Ayuntamiento de Matanzas;

38 García Rodríguez, Gloria, "Estudio introductorio", en Francisco de Arango y Parreño, Obras, Biblioteca Clásicos cubanos, vol. I, Imagen Contemporánea, La Habana, 2005, pp. 38-40.

39 ARAngo y PARREÑo, Francisco, Obras, Publicaciones de la Dirección de Cultura del Ministerio de Educación, vols. I y II, La Habana, 1952. CARRILlo y ARANGO, Anastasio, Obras del excelentísimo Sr. Arango y Parreño, vols. I y II, Imprenta Manuel Galiano, Madrid, 1869.

40 Jorge Ibarra señala que fue redactado por Antonio del Valle, secretario de Arango y Parreño (IBARRA, Jorge, Varela el precursor. Un estudio de época, Editorial Ciencias Sociales, La Habana, 2008, p. 69), lo cual es negado por otros historiadores. La explicación de la confusión es que el memorándum se conecta con el documento "Representación de la Ciudad de La Habana a las Cortes, de 20 de julio de 2011" redactado por Arango y Parreño a solicitud del Ayuntamiento de la Habana, el Consulado de Agricultura y Comercio y la Real Sociedad Patriótica, que expuso la postura de la sacarocracia sobre la abolición de la esclavitud que se debatía en las Cortes.

41 Agustín Caballero, José, "Exposición a Cortes a las Cotes españolas”, en Obras, Biblioteca clásicos cubanos, Imagen Contemporánea, La Habana, 1999, pp. 214-236.

42 LeIVA LAJARA, Edelberto, “Estudio introductorio”, en José Agustín Caballero, Obras, Biblioteca Clásicos cubanos, Imagen Contemporánea, La Habana, 1999, p. 90.

43 FRANCO PÉREZ; Antonio-Filiú, "Vae victis;, o biografía politica del autonomismo cubano (18781898)”, Revista de Historia Constitucional, Núm. 3, 2002, pp. 257-279. 
se presentó en este órgano el 12 de abril de 1822 bajo el título "variaciones qe propongo qe se hagan a la Constitución de la Monarquía Española para esta Isla esclusivamente" (Sic). El propósito era que se remitiera a las Cortes, pero fue archivado al considerarse "peligroso", "dañoso" y "provocador de inquietud al público". ${ }^{44}$

El memorándum prosigue la linea particularista, autonomista y sin ruptura con la península iniciada por José Agustín Caballero. En el discurso de presentación, Zequeira señaló: "Nuestras Leyes son decretadas por hombres que careciendo de los conocimientos necesarios de este país (...), no pueden sino por una rareza inconcebible, acertar con lo que nos conviene (...) siendo tan diferentes las circunstancias de esta isla de las de cualquier otra parte de la nación, necesita de leyes particulares (...) Nada perderás, querida madre patria mía, y ganarás mucho en todo lo que ganemos acá (...)"45

El 15 de diciembre de 1822 en el marco del Trienio Liberal, se presentó en las Cortes una iniciativa bajo el nombre "Instrucción para el gobierno económico y politico de las provincias de Ultramar" auspiciada por los diputados Félix Varela, Leonardo Santos Suárez, José María Quiñones, Tomás Gener y José de las Cuevas. La iniciativa se aprobó y paso a comisión, entregándose la versión final el 16 de febrero de 1823 suscrita por los tres primeros diputados y Pablo Santafé, José Meléndez, Manuel Vizmanos y Ramón Luis Escovedo. ${ }^{46}$ Se sancionó, pero Fernando VII en los reales decretos de 1ro de octubre y 25 de diciembre de 1823, declaró nulos y sin valor los actos aprobados durante el gobierno liberal.

El proyecto, reconocido como de autoria de Varela por la participación destacada de éste en su redacción y defensa, responde, también, a la concepción de que la Isla requiere de un tratamiento particular. Expone en el preámbulo que las peculiares geográficas y demográficas inciden en “(...) que el régimen político se haga sobremanera dificultoso (...)", 47 abogando de manera contundente que los anteriores, por un gobierno autonómico. 48

44 Expediente sobre el proyecto de reforma de nuestra Constitución politica escrito por D. Gabriel Claudio de Sequeira, vecino de Matanzas. ANC, Fondo Asuntos Políticos, 1822, Leg. 20, Exp.94-95

45 "Indicación que hizo D. Gabriel Claudio de Sequeira en la sesión que tuvo la Comisión del Ayuntamiento de la Ciudad de Matanzas para instrucciones de Diputados a Cortes por esta provincia, el 1ro de abril de 1822", en Expediente sobre el proyecto de reforma de nuestra Constitución politica escrito por D. Gabriel Claudio de Sequeira, vecino de Matanzas. Archivo Nacional de Cuba, Fondo Asuntos Políticos, 1822, folios 8-9, 16-18, 21.

46 FrANCO PÉREz; Antonio-Filiú, Cuba en los orígenes del constitucionalismo español: la alternativa descentralizadora (1801-1837), ob. cit., pp. 231-234.

47 Varela Morales, Félix, Proyecto de Instrucción para el gobierno económico-politico de las provincias de Ultramar, Imprenta de Tomás Albán y Cia., Madrid, 1823.

48 La radicalización posterior del pensamiento de Varela a posiciones independentista y abolicionista ha inducido que algunos historiadores sostengan que el tono de corte reformistaautonomista de su proyecto fue una táctica para lograr concesiones que permitieran posteriormente la ruptura con España, idea que nos parece especulativa. Ver, TORRES CUEVAS, Eduardo, Félix Varela: los origenes de la ciencia y con-ciencia cubanas, Editorial Ciencias Sociales, La Habana, 1995, pp. 299 y ss. REYES FERnÁNDEZ, Eusebio, Félix Varela, 1788-1853, Editora Politica, La Habana, 1989, pp. 59-60. IBARRA CuestA, Jorge, Varela, el precursor. Un estudio de época, Editorial Ciencias Sociales, La Habana, 2008, p. 70. 
De Varela debe destacarse por la importancia que tuvo en la formación del pensamiento liberal de la época, ${ }^{49}$ las lecciones constitucionales que desempeñó durante unos meses de 1821 en el Seminario de San Carlos y San Ambrosio, bajo el auspicio de la Real Sociedad Patriótica de La Habana y a instancia del Obispo Juan José Díaz Espada y Fernández de Landa. ${ }^{50}$ La cátedra de la libertad, de los derechos del hombre, de las garantías nacionales y de las virtudes cívicas, ${ }^{51}$ como la denominó el presbítero en su inauguración, funcionó paralela a la que impartió en la Real y Pontificia Universidad de San Gerónimo, Prudencio Hechevarría. De las lecciones devino la primera obra cubana de derecho constitucional: "Observaciones sobre la Constitución politica de la Monarquía española", publicada en ese año por la Imprenta D. Pedro Nolasco Palmen e Hijo.

El proyecto constitucional de Joaquín Infantes se alejó de la línea reformistadescentralizadora porque se concibió para una Cuba separada de España. ${ }^{52} \mathrm{Su}$ escritura se vincula con la fracasada conspiración ${ }^{53}$ en la que participó Infantes junto a otros miembros de la logia masónica "El Templo de las Virtudes Teologales" en octubre de $1810 .{ }^{54}$ Sobre su data se manejan tres fechas 1810 , 1811 y 1812, aunque la versión más aceptada es que fue redactado en 1811 en Venezuela e impreso en 1812 en la imprenta de Juan Baillío. ${ }^{55}$ La confusión se suscita por dos razones fundamentales: en la introducción el documento plantea: "Malogrado el conato que dio motivo a este Proyecto (...)," de lo que puede

49 Ver, TORRes Cuevas, Eduardo, Félix Varela: los origenes de la ciencia y con-ciencia cubanas, ob. cit., pp. 91 y ss. HernÁndez TRAVIESO, Antonio, El padre Varela. Biografía del forjador de la conciencia cubana, 2da. edición, Ediciones Universal, La Habana, 1984. ZAMORA, Juan Clemente, "Historia de una Cátedra", Anuario de la Facultad de Ciencias Sociales y Derecho Público, La Habana, 1954, pp. 9-17.

50 ZALDÍVAR ABAD, Martha Loyda, "El obispo Espada: génesis del sentimiento constitucional por Cádiz en Cuba”, en Andry Matilla Correa y Marcos F. Massó Garrote (comp.), De Cádiz (1812) a La Habana (2012). Escritos con motivo del bicentenario de la constitución española de 1812, ob. cit., pp. $124-138$

51 Varela Morales, Félix, "Discurso inaugural”, en Escritos politicos, Editorial Ciencias Sociales, La Habana, 1977, p. 25.

52 Infante, Joaquín, Proyecto de Constitución para la Isla de Cuba., Academia Nacional de Historia, Ediciones Guadarrama, Venezuela, 1954.

53 Tras el fracaso de la conspiración, Infante huyó Venezuela. Tuvo una intensa actividad revolucionaria en el continente, involucrándose con los independentistas en Venezuela y México y cumpliendo misiones de Simón Bolivar, hechos por los que estuvo preso en varias ocasiones.

54 En las primeras décadas del siglo XIX se produjeron diversos movimientos conspirativos organizados desde logias francmasonas: "El templo de las virtudes teologales" (1809), "Los Soles y Rayos de Bolivar", la "Cadena Triangular" (1822) y la "Gran Logia del Águila Negra" (1825). La inconformidad hacia el statu quo, se expresó también en la propuesta que realizaron un grupo de criollos a Simón Bolivar para que dirigiera una acción armada que liberara a la Isla, intención que tuvo un momento importante en el Congreso de Panamá en 1826 y el plan colombo-mexicano de invasión. Son muestra también del sentimiento de rebeldía que iba calando, las insurrecciones de Francisco Agüero Velasco (1826) y Joaquín de Agüero y Agüero (1851).

55 Bernal Gómez, Beatriz, "El primer proyecto de constitución independentista para Cuba", en Estudios juridicos en homenaje a María Morineau, vol. I, Instituto de Investigaciones Juridicas, UNAM, México, 2006, p. 65. FERnÁndez Bulté, Julio, Historia del Estado y el Derecho en Cuba, ob. cit., pp. 63-80. SUAREz, Reynaldo, "Anticipándose a Cádiz: el Proyecto Constitucional para la Isla de Cuba de Joaquín Infantes”, en Andry Matilla Correa y Marcos F. Massó Garrote (comp.), De Cádiz (1812) a La Habana (2012). Escritos con motivo del bicentenario de la constitución española de 1812 , ob. cit., pp. 32 y ss. 
inferirse que se escribió en 1811 después de abortada la conspiración; por otro lado, en el juicio que se le práctico en Venezuela en 1813 por tomar parte del movimiento independentista en ese país, el autor dijo que lo había escrito en abril de 1810 en Venezuela, lo cual no era cierto porque en esa fecha aún se encontraba en Cuba.

Fue un texto extenso, abarcador, minucioso, disperso en sus contenidos, que, junto a los poderes legislativo, ejecutivo y judicial, reconoció el poder militar.

El proyecto de Constitución de Narciso López de Urriola56 (1851) es el más breve de los analizados, aunque presenta dos elementos distintivos: enuncia a la República de Cuba y describe la bandera cubana diseñada junto al escudo, por Miguel Teurbe Tolón a solitud suya. Se pensó como provisional para el gobierno que se formaría una vez que triunfara la revolución y hasta tanto se convocara una asamblea constituyente. Declaró en el artículo primero que "cesa y queda anulada para siempre la autoridad de la corona de España en la Isla de Cuba, y esta se constituye en República libre e independiente, con el nombre de República de Cuba”. 57

El análisis exegético de los legajos evidencia que las obras de José Agustín Caballero, Gabriel Claudio Zequeira y Félix Varela y Morales, manifiestan una linea de pensamiento reformista-descentralizador, mientras que los de Joaquín Infante y Narciso López, se concibieron para una Cuba separada de España. De estos documentos, contaron con determinada hechura técnico-constitucional, los correspondientes a Infante, Varela y López; y llegaron a entregarse a diputados para su presentación a Cortes, los informes de Arango, Caballero, y Varela.

\section{EL DERECHO CONSTITUCIONAL MAMBÍ 58}

Esta fuente se integra por las cartas magnas promulgadas durante la guerra de independencia en contra España, circunstancia que marcó su esencia revolucionaria e independentista. Se reconocen por el nombre del territorio donde se redactaron: Guáimaro, 1869; Baraguá, 1878; Jimaguayú, 1895 y la Yaya, 1897.

La Constitución de Guáimaro se gestó en un proceso que comenzó el 10 abril de 1869 en horas de la mañana y culminó dos dias después con la toma de

56 Narciso López, de origen venezolano, se unió al ejército español donde adquirió el grado de Mayor General. Se asentó en La Habana en 1823 y llegó a desempeñar el cargo de Teniente Gobernado de Trinidad. Se relacionó con los líderes del anexionismo en Cuba y con las acciones del Club de La Habana por lograr un acuerdo para la compra de la Isla por Estados Unidos. Organizó la conspiración de la Mina de la Rosa Cubana y varios intentos de invasión desde el anterior país, en el último de ellos efectuado en 1851, fue apresado y ejecutado.

57 CARRERAS, Julio Ángel, Historia del Estado y el Derecho en Cuba, ob. cit., pp. 166-170.

58 Sobre el origen del término mambi existen diferentes explicaciones, dos resultan las más reconocidas. Una señala que el vocablo proviene de Santo Domingo en donde los españoles la emplearon para identificar a los rebeldes y cimarrones. Alli, la palabra tenía dos usos, denominaba a los animales que se escapaban de las crias y tomaban el campo, y se nombraba de igual manera a un árbol silvestre ramificado que utilizaban los rebeldes para esconderse. La otra tesis, más sólida según Fernando Ortiz, apunta que la palabra en el Congo significa hombre malo, perjudicial, repulsivo; siendo tomada por los españoles del léxico de los negros esclavos. ORTIZ, Fernando, Nuevo catauro de cubanismos, Ciencias Sociales, La Habana, 1974, p. 236. 
posesión de los electos. Sus características significativas fueron las siguientes: documento breve, sin subdivisiones, concebido como provisional durante la guerra; diseñó una organización de poder civil; asentó el concepto de soberanía nacional que depositaba en "los representantes del pueblo libre de la Isla de Cuba",59 cuestión que evidencia la idea de los padres fundadores de que gestaban un orden político diferente al Estado colonial; institucionalizó un mecanismo de poder integrado por la Cámara de Representantes y el presidente, con predominio de la asamblea; refrendó una estructura administrativa federal; reconoció la libertad como derecho, condenando la esclavitud que existía en la Isla.

El texto es trascendente, porque consagró jurídicamente la opción independentista, legalizó e institucionalizó la gesta insurrecta y aseguró la unidad política. ${ }^{60}$ Ramiro Guerra señaló con acierto que "dar cima a empeño tan arduo, fue el mérito excepcional, en el orden patriótico y político, de la gran asamblea revolucionaria. Los defectos técnicos podían considerase secundarios. El fin primordial perseguido quedó asegurado y eso era lo vital para la revolución cubana."61 Hernández Corujo destacó con precisión que "representa en la historia constitucional de Cuba el nacimiento de un régimen constitucional, democrático y republicano, sobre cuyas fundamentales bases se ha organizado después la vida constitucional de nuestra patria, — sin perjuicio de las posibles críticas técnicas, doctrinales y politicas que pueden dirigirsele-, ha podido ser calificada como el "símbolo glorioso" en nuestra Historia nacional."62 José Martí, con su prosa apasionada expresó que "en los modos y en el ejercicio la carta, se enredó, y cayó tal vez, el caballo libertador; y hubo yerro acaso en poner pesas a las alas, en cuanto a formas y regulaciones, pero nunca en escribir en ellas la palabra de luz."63

La carta de Baraguá fue expresión jurídica de la protesta del mismo nombre que repudió el Pacto del Zanjón que finalizó la guerra, acto que se reconoció como ilegítimo por no ser técnicamente pacto o convenio, por la capitis deminutio del comité que lo firmó y porque el artículo 14 de la ley suprema emitida en Guáimaro, señaló que la firma de la paz debía ser objeto de ley.

Se redactó el 15 de marzo de 1878 como instrumento provisional de seis artículos que estableció un órgano de gobierno que concentró el poder. En puridad, fue un estatuto con valor simbólico que expuso la voluntad de continuar la lucha hasta obtener la independencia; por ello, no es incluido en algunos estudios constitucionales. ${ }^{64}$

59 Constitución de Guáimaro, LAZcAno y MAZón, Andrés M., Las Constituciones de Cuba, Ediciones Cultura Hispánica, Madrid, 1952, p. 503.

60 Villabella Armengol, Carlos Manuel y Matilla Correa, Andry, Guáimaro, Alborada en la historia constitucional cubana, Ediciones Universidad, Camagüey, 2009.

61 Guerra, Ramiro, Guerra de los 10 años, vol. I, Ciencias Sociales, La Habana, 1972, p. 260.

62 Hernández CoRUJo, Enrique, "Significación y proyecciones de la Constitución de Guáimaro" Anuario de la Facultad de Ciencias Sociales y Derecho Público, Universidad de La Habana, Editora LEX, La Habana, 1950, p. 97.

63 MARTí, José, Obras Completas, vol. I, Editorial Ciencias Sociales, La Habana, 1991, p. 532.

64 HeRnÁndez CoRuJo, Enrique, Organización civil y politica de las revoluciones cubanas de 1869 y 1895, Imprenta y Papelería de Rambla y Bouza, La Habana, 1929, pp. 30 y ss. 
La ley fundamental de Jimaguayú se concibió en una asamblea que comenzó a sesionar el 13 de septiembre de 1895 y culminó cinco días después con la toma de posesión de los electos. Contó con los siguientes rasgos: documento breve, sin subdivisiones, con un párrafo introductorio que recoge enunciados éticoprogramáticos: "declarando previamente ante la patria la pureza de sus pensamientos, libres de violencias, de ira o de prevención y sólo inspirados en el propósito de interpretar en bien de Cuba los votos populares para la institución del régimen y gobierno provisionales de la República"65; declaró la conformación de la Isla como Estado independiente bajo el nombre de República de Cuba; instituyó un órgano de poder colegiado denominado Consejo de Gobierno que concentró todas las funciones, configurando una forma de gobierno convencional; postuló la vocación democrática del régimen que instituía; no refrendó derechos.

Algunos autores han señalado que el texto no puede reconocerse técnicamente como constitución al carecer de atributos de ésta, entre ellos, el refrendo de derechos. 66

La Carta Magna de la Yaya resultó de una convención que se reunió a tenor de lo estipulado en la anterior, desarrollándose entre el 19 de septiembre y el 30 de octubre de 1897, fecha en que prestó juramento el nuevo gobierno. Además de redactarla, el cónclave atendió los informes que rindieron los funcionarios públicos saliente, lo que, unido a la factura técnica de la norma, evidencia el desarrollo alcanzado por el constitucionalismo mambí. Se caracterizó por los siguientes aspectos: ordenó el contenido en títulos y secciones, contando con un preámbulo y partes orgánica y dogmática; delimitó el territorio de la Isla; definió la obtención de la ciudadanía a partir de los principios ius solis y ius sanguinis, y la prestación de servicios a la patria; refrendó derechos civiles y políticos, estipulando la posibilidad de su suspensión; reguló al Consejo de Gobierno como órgano colegiado que concentró todas la funciones, consolidando el modelo de gobierno diseñado en Jimaguayú; deslindó la administración de justicia civil de la militar; y contempló la existencia del poder constituyente originario al regular las ocasiones en que debia reunirse la asamblea de representantes.

Estos textos fundaron el derecho constitucional cubano y expusieron el decurso formativo de la nacionalidad cubana, ${ }^{67}$ en tanto la guerra de la que emanaron fue "la matriz de la nación". ${ }^{68}$ Fueron gestadas para legitimar la beligerancia, acogieron los principios liberales, entre ellas hubo progresión técnica, optaron por una organización del poder civil y enmarcaron el surgimiento del Estado y el derecho cubano.

Se destacan, las leyes supremas de Guáimaro y la Yaya. La primera, significó la alborada del constitucionalismo patrio, legitimó la guerra de liberación y configuró una forma de gobierno asambleario. La segunda, fue la más completa $\mathrm{y}$ acabada técnicamente, por lo que es la única que pudiera considerarse en

65 Constitución de Jimaguayú, LAzCAno y Mazón, Andrés M., Las Constituciones de Cuba, ob. cit., p. 513.

66 LazCANo y Mazón, Andrés M., Las Constituciones de Cuba, ob. cit. p. 49.

67 AguIRre Sergio, Nacionalidad y nación en el siglo XIX cubano, Editorial Pablo de la Torriente, La Habana, 1995, pp. 54 y ss, ob. cit. pp. 10 y ss.

68 ViTIER, Cintio, Eso sol del mundo moral, Ediciones UNIÓN, La Habana, 1999, p. 51. 
estricto sensu como Constitución, consolidó el modelo de gobierno convencional establecido en 1895.

\section{EL DERECHO CONSTITUCIONAL NACIONAL BURGUÉS}

Esta fuente se integra por seis documentos: la Constitución de 1901, la reforma de 1928, el Estatuto para el Gobierno Provisional de 1933, la Ley Constitucional del Gobierno Provisional de 1934, la Ley Constitucional de 1935, la Constitución de 1940 y el Estatuto Constitucional de 1952.

La Carta Magna de 1901 promulgada por la Orden Militar 181 del 20 de mayo de 1902, resultó de un proceso de elaboración que se extendió del 5 de noviembre de 1900 al 21 de febrero del siguiente año, aunque la asamblea continuó sesionando hasta septiembre debatiendo el marco jurídico de las relaciones con Estados Unidos, tema que resultó el más tenso y polémico de la agenda por la presión a que fueron sometidos los delegados para que suscribieran la Constitución con el addendum de la "Enmienda Platt". 69

Este instrumento cercenó la independencia y soberanía al imponer condiciones para las relaciones exteriores de Cuba, excluir la Isla de Pinos del territorio nacional, estipular la entrega de tierras para la construcción de carboneras o estaciones navales y legitimar el derecho de intervención de los Estados Unidos. A tenor de esa prerrogativa se efectuó una segunda intervención de 1906 a $1909,{ }^{70}$ y tropas militares ocuparon parte del territorio en $1912^{71} \mathrm{y}$ $1917 .{ }^{72}$

La Resolución Conjunta aprobada por el Congreso de Estados Unidos el 18 de abril 1898 y el Presidente McKinley el día 20, legitimó la intervención de Estados Unidos en la guerra hispano-cubana: "El pueblo de la Isla de Cuba es y de derecho debe de ser libre e independiente (...) los Estados Unidos por la presente declaran que no tienen deseo ni intención de ejercer soberanía, jurisdicción o dominio sobre dicha Isla (...)"; ${ }^{73}$ sin embargo, en realidad, la intrusión fue la consecución de añejos intereses sobre la Isla, evidenciado en el aliento a las posturas anexionistas de un sector del patriciado cubano, la obstrucción de expediciones y envío de recursos de la emigración cubana, el no

69 Enmienda propuesta por el senador Orville Hitchcock Platt a la Ley sobre apropiaciones del Ejército norteamericano en 1901. El proceso de constitucionalización de las relaciones de Cuba con Estados Unidos y las presiones a que fueron sometidos los convencionales hasta el punto de planteárseles la disyuntiva de aprobar la Enmienda sin cambios o la ocupación norteamericana continuaría indefinidamente, puede consultarse en ROIG DE LEUCHSENRING, Emilio, Historia de la Enmienda Platt, Instituto Cubano del Libro, La Habana, 1961.

70 Yglesia Martínez, Teresita, Cuba, primera República, segunda ocupación, Editorial Ciencias Sociales, La Habana, 1976, pp. 225-415.

71 El motivo fue el alzamiento protagonizado en 1912 por el partido los Independientes de Color. El 5 de junio fueron desplazados 450 infantes en Guantánamo y el 7 de ese mes desembarcaron más soldados en Santiago de Cuba.

72 Producto de la revuelta de civiles y militares producida en febrero de 1917 en la región centro-oriental, conocida como "La Chambelona", desembarcaron 2600 infantes de marines y ocuparon regiones en Santiago de Cuba y Camagüey.

73 PichaRdo, Hortensia, Documentos para la historia de Cuba, vol. I, Editorial Ciencias Sociales, La Habana, 1971, pp. 508-510. 
reconocimiento de la personalidad de la República en armas, y los diferentes intentos de compra de Cuba a España: ${ }^{74}$

“(...) la situación geográfica -fatalmente excepcional- de Cuba (...) la riqueza y feracidad extraordinaria de su suelo (...) y su proximidad al territorio de la Unión. Han hecho que nuestra Isla fuese, presa codiciada, necesaria en la expansión comercial de los Estados Unidos e imprescindible para la defensa de sus mares y costas (...) Todos los Gobiernos norteamericanos (...) han de ver (...) la necesidad que los Estados Unidos tienen de poseer la Isla, solo variara el procedimiento para apoderarse de ella: anexión, compra, ocupación militar, república sometida al control de Washington mediante la Enmienda Platt, dominio de su economía; diversas formas de que la fruta madura caiga en sus manos. ${ }^{75}$

Esta Constitución recogió los postulados del liberalismo decimonónico y estuvo influida por la Carta Magna norteamericana en varios contenidos. Como asevera Gay-Galbó: "fue una de las hijas retrasadas de la Revolución francesa y la Enciclopedia".76

Sus características fundamentales fueron las siguientes: reguló los derechos individuales desde un acento iusnaturalista; instituyó un control jurisdiccional de la Constitución concentrado en el Tribunal Supremo a petición de partes; adoptó una forma de gobierno presidencial sobre un esquema orgánico de influencia norteamericana; acogió un sistema de democracia representativa en el que no se reconoció el derecho al voto de las mujeres y el presidente era elegido de manera indirecta; refrendó una forma de Estado unitaria; asumió un régimen de gobierno local con el modelo organizativo de gobernador-consejo provincial y alcalde-ayuntamiento; refrendó un procedimiento de reforma rígida (contemplaba que la enmienda debía ser aprobada por mayoría de las dos terceras partes de cada cámara y ratificada por una convención reunida seis meses después).

En función de los rasgos descritos, Orestes Ferrara reconoció con tino que era una Constitución individualista, que refrendaba un Estado liberal organizado sobre la división de poderes, conformado en base a los principios de la democracia representativa, y cuyo cometido era la protección de las libertades individuales. ${ }^{77}$

74 En 1809 el General James Wilkinson, agente del Presidente Jefferson (1800-1808), viajó a La Habana para proponerle al Capitán General Salvador José Moro y Salazar, la incorporación de la Isla a los Estados Unidos en razón de la situación en que se encontraba la península bajo la invasión francesa. El Presidente James Polo (1845 - 1849) propuso la compra de la Isla por 100 millones. El Presidente Franklin Pierce (1853- 1857) realizó una propuesta similar por 130 millones de pesos (CANTÓn NAVARRo, José; ZANETTI LECuONA, Oscar; ÁlvAREZ-TABIO LongA, Pedro; et. al., Historia de Cuba. La neocolonia. Organización y crisis desde 1899 hasta 1940, Editorial Félix Varela, La Habana, 2004, pp. 93, 120).

75 Roig DE Leuchsenring, Emilio, Los Estados Unidos contra Cuba libre, Editorial Oriente, Santiago de Cuba,1982. pp. 3-22, 227-238.

76 Gay-Galbó, Enrique, Nuestro Problema Constitucional, Librería Nueva, La Habana, 1936, p. 14.

77 FERRARA, Orestes, Las ideas juridico-sociales en las constituciones cubanas, conferencia pronunciada en el ilustre Colegio de Abogados de Madrid el 29 de enero de 1945, Talleres Gráficos Marsiega, Madrid, 1945, p. 26. 
La institucionalidad creada en 1902 quebró cuatro años después. En 1906 se produjo una nueva intervención de los Estados Unidos, en este caso, a solicitud del Presidente Tomás Estrada Palma ante la convulsión social que produjo su reelección fraudulenta. Hasta enero de 1909 en que tomó posesión el Presidente José Miguel Gómez, administró el país el funcionario norteamericano Charles Edwar Magoon.

La precariedad del régimen constitucional puede aquilatarse también porque desde 1908 comenzó a esbozarse la necesidad de reformas a la Carta Magna, lo que se concretaría unos años después. En agosto de 1912 el senador Antonio Berenguer y Sed78 entregó una iniciativa de enmienda al legislativo; en junio de 1913 Ricardo Dolz y Arango depositó otra;79 en enero de 1918 el diputado José María Lasa presentó una tercera; 80 y en mayo de 1921 Alfredo Zayas al asumir la presidencia, recomendó al Congreso considerar la reforma de varios artículos, creándose una comisión por el Senado que laboró en la idea hasta 1822. Todas las propuestas concurrian en la organización y funcionamiento del gobierno, algunas, introduciendo dinámicas parlamentarias $y$ otras reforzando el ejecutivo. 81

En marzo de 1927 bajo la presidencia de Gerardo Machado y Morales, el representante Giordano Hernández presentó un nuevo proyecto que fue secundado por otros diputados, aprobándose en ambas cámaras y convocándose a una asamblea constituyente que fue electa con irregularidades. El cónclave sesionó del 14 de abril de 1927 al 10 de mayo de 1928, emergiendo un texto que fue reconocido por algunos autores de la época como una nueva ley fundamental, mientras otros señalaron, con acierto, que era una reforma ilegitima porque la asamblea rebasó la misión para la que se convocó y actuó al margen de la cláusula de reforma: "fue un golpe de estado contra la soberanía popular",82 "el Estado de Derecho "tornóse en torticero" (...) porque el artículo 115 había sido violado (...) se rompió el ritmo constitucional y el cambio no respondió más que al propósito (del Presidente) de perpetuarse en el mando." ${ }^{3}$ La transgresión del procedimiento de reforma fue reclamada en varios demandas interpuestas ante el

78 República de Cuba, Senado, Proposición de Ley del Dr. Antonio Berenguer y Sed, sobre la revisión constitucional, presentada al Senado en sesión del 12 de agosto de 1912, Imprenta y Librería "La Moderna Poesia", La Habana, 1912.

79 Dolz Y ARANGo, Ricardo, “Proyecto presentado por el senador Ricardo Dolz", La Reforma Social, vol. X, Núm. 3, Casa Editorial La Reforma, Nueva York, 1918.

80 LASA, José María, Projecto presentando por el representante José María Lasa, La Reforma Social, vol. X, Núm. 3, Casa Editorial La Reforma, Nueva York, 1918.

81 Ver FERRARA, Orestes, "La reforma constitucional en Cuba”, en La Reforma social vol. X, Núm. 2, Casa Editorial La Reforma, Nueva York, 1918. Mulet MARTínez, Fabricio, Entre la crisis y la reforma. Itinerario del constitucionalismo cubano (1906-1933), Pensamiento Constitucional, Núm. 2, 2017, pp. 143-173. MAÑAS, Arturo, Sobre una reforma de la constitución cubana, Imprenta F. Verdugo, La Habana, 1931.

82 LazCano y Mazón, Andrés M., Las Constituciones de Cuba, ob. cit. p. 93.

83 Álvarez Tabío, Fernando, Evolución constitucional de Cuba (1928-1940), Talleres Gráficos O`Reilly 259, La Habana, 1953, p. 11. 
Tribunal Supremo y reconocido tardiamente en la Sentencia número 72 del 12 de mayo de 1931.84

El documento asumió el contenido del texto anterior, modificando dieciocho artículos y algunas disposiciones transitorias: incluyó la Isla de Pinos en los límites del territorio nacional; reconoció el derecho al sufragio femenino; aumentó el número de senadores a nueve por provincia y elevó su mandato a nueve años; legitimó que el presidente se convirtiera en senador por derecho propio cuando culminara en el cargo; extendió el periodo de los diputados a seis años; eliminó la facultad del Congreso de designar al titular del ejecutivo en caso de que falleciera o renunciase, y trazó una línea sucesoria para éste (secretario de Estado, presidente del Tribunal Supremo, magistrado de mayor edad); le reconoció iniciativa legislativa al presidente; prorrogó el término de su mandato a seis años y aprobó su reelección para un periodo más; añadió al procedimiento de reforma el requisito de mayoría cualificada y el plebiscito (en caso de que se introdujera una enmienda de reelección presidencial o la prórroga del mandato de algún cargo electivo). ${ }^{85}$

En agosto de 1933 Gerardo Machado solicitó al Congreso licencia para abandonar el país presionado por el movimiento social que impulso su derrocamiento. El día 24 de ese mes, el Presidente interino Carlos Manuel de Céspedes, mediante el Decreto 1298, restableció la Constitución de 1901, destituyó a los funcionarios que habían sido electos al amparo de la ley de 1928 y disolvió el Congreso.

Sobrevino a partir de este año un período de inestabilidad políticoconstitucional en el que se sucedieron varios presidentes de facto y diversas leyes constitucionales. ${ }^{86}$ Algunos de los gobernantes de la etapa solo duraron horas: Carlos Manuel de Céspedes (13 de agosto al 4 de septiembre de 1933), Pentarquía (4 de septiembre al 10 de septiembre de 1933), Ramón Grau San Martín (10 de septiembre de 1933 a 16 de enero de 1934), Carlos Hevia y Reyes Gavilán (16-17 de enero de 1934), Carlos Mendieta Montefur (17 de enero de 1934 a 12 de diciembre de 1935), José Barnet Vinageras (12 de diciembre de 1935 a 20 de mayo de 1936). En mayo de 1936 se produjeron elecciones en las que resultó seleccionado Miguel Mariano Gómez, quien fue depuesto unos meses después por el Congreso (20 de mayo al 24 de diciembre de 1936), siendo sustituido por el vicepresidente Federico Laredo Brú (24 de diciembre de 1936 a 10 de octubre de 1940).

El 14 de septiembre de 1933 el Presidente Ramón Grau San Martín al asumir el poder repudió la Carta Magna de 1901 por contener la "Enmienda Platt" y promulgó los Estatutos para el Gobierno Provisional de Cuba. Este instrumento de gobierno realizó en la introducción un recuento de la lucha por la

84 Gutiérrez y SÁnchez, Gustavo, Historia del Derecho Constitucional cubano, Cultural S. A., La Habana, 1938, p. XXIII.

85 Reforma de la Constitución aprobada por el Congreso y aceptada por los delegados del pueblo de Cuba en Convención Constituyente, Gaceta Oficial de la República, Edición Extraordinaria Núm, 6, 11 de mayo de 1928. MAÑAs, Arturo, La Convención Constituyente del Artículo 115 , Imprenta F. Verdugo, La Habana, 1928.

86 Para un análisis del derrotero constitucional de esta etapa: Mulet MARTíNEZ, Fabricio, "El desarrollo constitucional de Cuba, durante los años 1933-1939", Revista Cubana de Derecho, Núm., 54, julio-diciembre 2017, pp. 71-101. 
independencia y expuso los principios que sostendría el gobierno en politica interna e internacional, planteó la creación de tribunales para perseguir los delitos políticos cometidos por funcionarios del anterior régimen, reguló la suspensión de derechos y proclamó la conformación de una convención constitucional. El Decreto 3333 de 26 de diciembre, adicionó un párrafo que amplió la facultad de los tribunales para perseguir los delitos contra el patrimonio público y privado.

El 23 de febrero de 1934 el Presidente provisional Carlos Mendieta promulgó una Ley Constitucional que, en un extenso preámbulo argumentó que no se restauraba la ley fundamental de inicios de siglo: "atendiendo al estado de opinión que en el espíritu público se ha formado contra la Constitución de 1901, y habida cuenta de que muchos de los Títulos (...) carecen de aplicación (se) ha estimado como más conveniente promulgar preceptos constitucionales que (...) la adaptasen a las necesidades del momento actual". ${ }^{87}$ La ley asumió la normativa de 1901 introduciendo algunas novedades: incorporó a la Isla de Pinos en la descripción del territorio nacional; añadió supuestos para la obtención de la ciudadanía por nacimiento (ius solis) y naturalización, y para la perdida de ésta; incluyó el derecho de inviolabilidad de la comunicaciones telefónicas y el habeas corpus; normó el régimen jurídico de los extranjeros; consagró el derecho al sufragio femenino; instituyó al ministerio fiscal; instituyó un sistema de poder público endogámico integrado por el presidente, el Consejo de Secretarios como órgano ejecutivo, legislativo (emitía decretos-leyes) y de gobierno, y el Consejo de Estado como ente asesor del ejecutivo; amplió las garantitas de los derechos con la acción pública individual y colectiva; y modificó la cláusula de reforma flexibilizándola (se exigía el voto de dos tercios de los consejo de secretarios y de Estado). Durante su efimera existencia, tuvo trece reformas y se le añadieron tres disposiciones transitorias.

La Resolución Conjunta de 8 de marzo de 1935 suspendió la ley anterior y decretó un estado de emergencia, regulando un mecanismo de poder ad hoc integrado por el presidente provisional, el secretario de la presidencia, varios secretarios de Estado, el presidente del Consejo de Estado y el alcalde municipal de La Habana. El ejecutivo tenía facultad para dictar las medidas necesarias para restablecer la normalidad.

Unos meses después, el 11 de junio de 1935, el Presidente Mendieta dictó otra Ley Constitucional que retomó el texto de 1901, añadiendo alrededor de doce artículos y 30 disposiciones transitorias que ordenaron el régimen de gobierno que fungiria provisionalmente hasta las elecciones generales que se producirian al año siguiente. Efectuadas éstas, el 20 de mayo de 1936 entró a regir integramente.

Entre los preceptos que incorporó se encuentran los siguientes: enunció los nombres de las seis provincias en que se dividia el país; planteó una cláusula de protección del ciudadano cubano frente al extranjero en relación con el derecho el trabajo; estipuló la responsabilidad del Estado de asegurar la segunda enseñanza y la enseñanza superior; atribuyó al Tribunal Supremo la función de pronunciarse sobre la constitucionalidad de las leyes y actos de poder, a

87 Ley Constitucional de 1934, LazCAno y Mazón, Andrés M., Las Constituciones de Cuba, ob. cit., p. 625. 
instancia de parte afectada respecto a los derechos o por petición colectiva de veinticinco ciudadanos.

Expresión de la crisis político-constitucional de estas décadas fueron, asimismo, la cantidad de proyectos constitucionales que se elaboraron propugnando la reforma del Estado como vía para solucionar la inestabilidad social: idea de ejecutivo colegiado asistido por el Consejo Supremo de la Administración planteada por Mario García Kohly; concepción de gobierno convencional de Arturo Mañas, José Portuondo y de Castro, ${ }^{88}$ y Juan Casasús; 89 propuesta de organización estatal con cinco poderes (ejecutivo, legislativo, judicial, cultural y económico-social) de César Rodríguez Morini;90 gobierno técnico-funcional de J. L. Ábalo.91 En el Congreso, fueron valorados los proyectos del representante Carlos Manuel de la Cruz y el senador José Manuel Cortina. ${ }^{92}$

El 16 de diciembre de 1936 el Congreso aprobó un proyecto de Constitución, convocó a una constituyente y modificó el artículo 115 de la ley fundamental 1901 que regulaba el procedimiento de reforma. La elección de la asamblea se dilató por la inestabilidad política del país, conformándose, finalmente, el 9 de febrero de 1940. En su primera sesión, la convención ratificó su carácter soberano para redactar una nueva ley suprema. Concluyó sus labores el 8 de junio de 1940, el 1ro de julio se firmó la nueva carta en Guáimaro y el día 5 se promulgó en la escalinata del Capitolio.

De la Carta Magna de 1940 sobresale su extensión; el tono reglamentista que asumió en algunos temas; la técnica de condicionar la efectividad de normas de leyes complementarias que en su mayoría no se emitieron (en 250 ocasiones, aproximadamente, hubo remisión a leyes de desarrollo, empero, de 1941 a 1950 que se promulgaron 224 leyes, alrededor de 19, solamente, obedecieron a esta condición);93 su proyección social; carácter renovador que adoptó en diversos contenidos. Fueron innovaciones: la regulación del régimen económico, el refrendo de derechos sociales, el rediseño de la forma de gobierno presidencial con principios del parlamentarismo, el sistema de control de constitucionalidad que consagró y la ordenación que realizó del régimen municipal. Tuvo un enfoque progresista: la protección a la familia, la maternidad, la niñez y la juventud; la

88 Portuondo y de CAstro, José, Proyecto de Constitución, Editorial Alberto Solo, La Habana, 1934.

89 CASAsús, Juan J., La Nueva Ciudad del Sol, Cultural, S.A., La Habana, 1937.

90 Rodríguez Morini, CÉsAr, Anteproyecto de Constitución Política, Económica y Social, Cultural S. A., La Habana, 1933.

91 ÁBalo, J.L., La Forma Técnico Funcional del Gobierno, Ediciones Montero, La Habana, 1939.

92 Elaboraron también proyectos Mariano Aramburo, Félix Pérez Porta, Enrique Loynaz del Castillo. Para un análisis de éstos consultar los estudios de MULET MARTínEz, Fabricio, Entre la crisis y la reforma. Itinerario del constitucionalismo cubano (1906-1933), Pensamiento Constitucional, Núm. 2, 2017, pp. 143-173. También: "Aproximación al pensamiento juridicoconstitucional cubano durante los años 1933-1939. El tránsito hacia un nuevo orden constitucional”, en Andry Matilla Correa, Osvaldo M. Álvarez Torres, Isnel Martínez Montenegro, Temas de Historia del Derecho y Derecho Agrario. Homenaje al profesor Orestes Hernández Más, Facultad de Derecho Universidad de La Habana, UNIJURIS, La Habana, 2013, pp. 293-323.

93 Borges, Milos A., Compilación ordenada y completa de la legislación cubana (1899-1859). Índice Alfabético, 2da. ed., Editorial LEX, La Habana,1952, pp. 391 - 1320. 
responsabilidad del Estado respecto a la educación; el refrendo de derechos laborales; la protección a la mujer trabajadora; la proscripción del latifundio.

El tono progresista fue condicionado por diversos aspectos, grosso modo pueden destacarse los siguientes: entre los delegados hubo consenso en conformar un documento que rompiera con el modelo constitucional de 1901; en la asamblea desembocó el clima revolucionario de la década del treinta, portador de demandas insatisfechas; la crisis del liberalismo económico favoreció que los contenidos sociales se convirtieran en ejes del proyecto constitucional; el ambiente internacional de lucha contra el fascismo propició un entorno favorable; los medios de comunicación dieron seguimiento a los debates, propiciando que la ciudadanía se manifestara en temas de la agenda constituyente y se convirtiera en un factor de presión; la apertura democrática producida en los años previos viabilizó la legalización del Partido Comunista en septiembre de 1938 y la fundación de la Confederación de Trabajadores de Cuba en enero de 1939, organizaciones que favorecieron la articulación de demandas sociales; la legislación electoral permitió la elección transparente de los delegados y obligó a los partidos a presentar sus programas al Tribunal Supremo, incidiendo ello en que se incluyeran en las plataformas tema sociales; los seis delegados del Partido Unión Revolucionaria Comunista introdujeron planteamientos radicales en casi todos los puntos proyecto constitucional.

Este documento precursor del constitucionalismo social tuvo las siguientes características: incorporó normas axiológicas y principios; reguló la ciudadanía de manera exhaustiva; empleó la categoría derechos fundamentales y refrendó un amplio listado de derechos en cuatro secciones (derechos individuales, familia y cultura, trabajo y propiedad, sufragio y oficios públicos) mandató al Estado con el desarrollo de políticas públicas en temas sociales; reguló el voto como derecho y deber; enunció la supremacía de la constitución; institucionalizó un sistema de control de constitucionalidad centralizado y semiespecializado en manos del Tribunal de Garantías Constitucionales y Sociales, al que se le reconoció amplias facultades; reguló diversas garantías a las libertades; contornó al municipio sobre el principio de autonomía municipal y le reconoció diferentes modalidades organizativas (comisión, ayuntamiento-gerente y alcalde-ayuntamiento); reformuló la forma de gobierno presidencial al incorporar el Consejo de Ministros como órgano de gobierno y reconocerle al legislativo mecanismos de control político sobre éste, contornando un presidencialismo atenuado; reguló un complejo procedimiento de reforma específica, parcial e integral, a iniciativa del pueblo o del Congreso y con ratificación mediante referendo o asamblea constituyente.

Algunos estudios de historia constitucional desde un maniqueísmo simplón, minimizaron los aportes de esta carta y la enjuiciaron por la inviabilidad práctica que tuvieron sus avanzados preceptos con los gobiernos de la época, ejemplo de ello es la siguiente afirmación: "no era otra cosa que una constitución tan burguesa y neo-colonial como las que le precedieron (...), además de hipócrita porque contenía esos pocos preceptos (...) que no eran verdaderamente revolucionarios". 94

94 Vega Vega, JuAn, Derecho Constitucional revolucionario en Cuba, Editorial Ciencias Sociales, La Habana, 1988, p. 60. 
En marzo de 1952 se efectúo un golpe de estado encabezado por el General Fulgencio Batista que cercenó la ilusión sembrada por el texto comentado. La ruptura democrática fue legalizada por el Estatuto Constitucional promulgado el 4 de abril, que, en una extensa declaración preliminar, "argumentó" la necesidad del derrocamiento militar. El instrumento reprodujo el texto del cuarenta, concentrándose los cambios sustanciales en el mecanismo estatal que quedó integrado por el presidente, el Consejo de Ministro encabezado por el anterior y que asumía la función legislativa, y el Consejo Consultivo. El artículo 256 planteó que el Consejo de Ministros elaboraria un proyecto de constitución que sería sometido a referéndum en las elecciones generales, éste no se elaboró, y el Decreto-Ley 1163 de 30 de octubre de 1953 restituyó la vigencia de la ley suprema derrocada un año antes.

Como se evidencia, la etapa republicana descrita se caracterizó por la inestabilidad política, las rupturas democráticas (desde el 20 de mayo de 1902 hasta el 1ro de enero de 1959, cuatro presidentes no culminaron su mandato, nueve fungieron como gobernantes provisionales $y$ tres fueron derrocados militarmente) y la fragilidad constitucional. Los documentos que la integraron expresaron la conformación y evolución del Estado-nación en condiciones de protectorado de los Estados Unidos, quien ejerció permanente injerencia en la política local a través de su embajada.

Sobresalen las leyes supremas de 1901 y 1940 porque emanaron de auténticos procesos constituyentes, refrendando paradigmas diferentes y convirtiéndose en cánones sobre los que se desplegaron sendos ciclos constitucionales. La Carta Magna de 1901 fungió como basamento jurídico del Estado de Derecho que nació con la culminación de la guerra, respondió al patrón del constitucionalismo liberal y refrendó una forma de gobierno presidencial. La Constitución de 1940 fue abarcadora en contenidos, principista, programática, novedosa, precursora del constitucionalismo social, e implementó un sistema de gobierno presidencial con rasgos del parlamentarismo. ${ }^{95}$

\section{EL DERECHO CONSTITUCIONAL REVOLUCIONARIO-SOCIALISTA}

Esta fuente se integra por tres textos: la Ley Fundamental de 1959, la Constitución de 1976 y la Constitución de 2019.

La Ley Fundamental de 7 de febrero de 1959 retomó la normativa de la Constitución de 1940, realizando cambios menores en la ciudanía y los derechos (en la naturalización se introdujo un inciso que permitió su obtención a extranjeros que hubieran participado en la revolución, y se legitimó la confiscación de la propiedad privada en determinados supuestos) y modificaciones sustanciales en la organización de poderes (el ejecutivo quedó en manos del presidente y el Consejo de Ministros, órgano que se convirtió en ente preponderante al detentar funciones legislativa, ejecutiva, gubernativa $\mathrm{y}$

95 Algunos estudiosos clasifican la forma de gobierno como semiparlamentaria, criterio que nos parece erróneo porque el Consejo de Ministros careció de funciones propias, el primer ministro se delineó como una figura que presidía el órgano ante la ausencia del presidente, y éste nombraba a los ministros con libertad sin necesidad de un voto de confianza del congreso. FUENTE, JORGE DE LA, Análisis Constitucional desde Jimaguayú hasta el 40, Editorial Ciencias Sociales, La Habana, 1989, p. 165. CARreras, Julio Ángel, Historia del Estado y el Derecho en Cuba, ob. cit., pp. 484 y ss. 
constituyente; a nivel local, se sucedieron diferentes fórmulas de gobierno: comisión; juntas de coordinación, ejecución e inspección; administración local; comité ejecutivo). 96

La adopción del texto mencionado se amparó en dos razones. Por un lado, su contenido progresista fungia de sostén a las transformaciones que el gobierno revolucionario se proponía acometer; por otra parte, la promulgación de una nueva carta constitucional resultaba inviable en las condiciones politicas en que se desarrollaba el emergente poder político.

La cláusula de reforma también fue modificada, regulándose un procedimiento expedito en manos del Consejo de Ministros. Se refrendó que las enmiendas serian aprobadas por votación de las dos terceras partes de los miembros del órgano, reiterada en tres ocasiones y ratificada por el presidente. Así, quedó acuñado un exordio que encabezó la prolija legislación de esos años:97 "En uso del Poder Constituyente que compete al Consejo de Ministros, se declara la presente Ley parte integrante de la Ley Fundamental de la República la que así queda adicionada. En consecuencia se otorga a ésta Ley fuerza y jerarquía constitucionales. "98

Además de los cientos de reforma que sufrió, la ley fundamental fue mutada a través de prácticas políticas, algunas de las que se realizaron en concentraciones públicas en las que se adoptaron decisiones o crearon organizaciones; exempli gratia, la Primera y Segunda Declaración de la Habana de 2 de septiembre de 1960 y 26 de julio de 1964 respectivamente, definieron principios de politica exterior. Así, el texto fue multi-reformado por vía normativa y convencional, transformándose su fórmula politica y rebasándose su techo ideológico, con lo cual, se difuminó como norma suprema y progresó una dilatada provisionalidad estatal de quince años:

El proceso destituyente/instituyente que comenzó en 1959 tuvo un momento final en los primeros años de la década del setenta con la redacción de 94 leyes sobre diversos ámbitos sociales e institucionales, que sentaron las bases para la consolidación del proceso político socialista. En ese tracto, se promulgó la Constitución en 1976. Ésta no se gestó en una constituyente como es usanza del constitucionalismo, sino que fue concebida por una comisión, sometida a consulta popular y aprobada en referendo (participó el 98\% de la población mayor de 16 años, obteniéndose el 97.7\% de votos afirmativos).

El texto institucionalizo el socialismo que se edificaba desde 1961 sin refrendo, y asumió los presupuestos ideológicos y teóricos del sistema. En

96 Folleto de Divulgación Legislativa. Proclamas y Leyes del Gobierno Provisional de la Revolución, Núm. 1, Editorial LEX, La Habana, 1959, p. 5.

97 En 1959 se promulgaron, aproximadamente, 693 leyes, en 1960 fueron 239, en 1961 se alcanzó la cifra de 77, y en 1962 llegaron a 96; ello, sin incluir otros actos normativos como decretos y resoluciones (Primer Índice Anual de la legislación Revolucionaria 1 ro de enero a 31 de Diciembre de 1959, Editorial LEX, La Habana, 1959. Segundo Índice Anual de la legislación Revolucionaria 1ro de enero a 31 de Diciembre de 1960, Editorial LEX, La Habana, 1960. Tercer Índice Anual de la legislación Revolucionaria 1ro de enero a 31 de Diciembre de 1961, Editorial LEX, La Habana, 1961. Cuarto Índice Anual de la legislación evolucionaria 1ro de enero a 31 de Diciembre de 1964, Editorial LEX, La Habana, 1964).

98 Ley de Reforma Agraria, olletos de Divulgación Legislativa. Leyes del Gobierno Provisional de la Revolución, Núm. VIII, Editorial LEX, La Habana, 1959, p. 13. 
particular, siguió el formato de algunas leyes supremas de la antigua Europa del este; así, se distanció del constitucionalismo precedente y desconoció valiosos antecedentes. Algunas características sobresalientes son las siguientes: extenso preámbulo de corte histórico e ideológico; capítulo pórtico con definiciones económico-políticas; ciudadanía como vínculo político del individuo con el Estado, diferenciándola de la nacionalidad; reconocimiento de derechos individuales básicos y refrendo de derechos económicos y sociales acompañados de las garantias materiales para su existencia; mecanismo estatal integrado por la Asamblea Nacional del Poder Popular como órgano supremo del Estado con facultad legislativa y constituyente, el Consejo de Estado como ente de la asamblea que la representa y ejecuta sus decisiones y el Consejo de Ministros como institución de gobierno; configuración de una forma de gobierno de semiconvencional;99 regulación de un mecanismo de protección política de la Constitución.

La jerarquía material de la preceptiva se resintió ab initio por varias razones: el texto no postuló su eficacia directa, quedaron contenidos pendientes de leyes complementarias (en 47 ocasiones remitió a leyes de desarrollo), no se concretó un mecanismo de control de constitucionalidad efectivo que propiciara la protección y actualización de la normativa, en algunos contenidos se empleó una retórica más política que jurídica. Durante su vigencia, tuvo tres enmiendas formales en 1978, 1992 y 2002.

El primer cambio fue nominal. Relevó el nombre de la Isla de Pinos por el de Isla de la Juventud en el artículo décimo.

La segunda reforma fue consecuencia de la desactualización abrupta del articulado producto de la desaparición del socialismo europeo y la desintegración de la Unión de Repúblicas Socialistas Soviética en 1991. Abarcó la mitad del articulado, actualizó preceptos, reformuló contenidos y adicionó instituciones; propiciando en algunos casos una mejor conexión histórica.

99 La dinámica estructural-funcional que diseñó la Constitución de 1976 es imposible de catalogar desde las formas de gobierno del derecho comparado. La hemos denominado semiconvencional tomando como patrón el modelo convencional que nació en Francia en las constituciones de 1793 y 1795 y hoy subsiste en Suiza. Las características del sistema cubano son las siguientes: i) la Asamblea Nacional del Poder Popular constituye el órgano máximo de poder del Estado; ii) el Consejo de Estado es órgano elegido y subordinado a la asamblea; iii) no existe un órgano ejecutivo como tal, el Consejo de Estado es ente colegiado que implementa las leyes y ejecutas las decisiones de la asamblea; iv) el Consejo de Estado, además, representa el poder de la asamblea cuando no se encuentra sesionando; iv) el Consejo de Ministros es el máximo órgano de gobierno, v) el premier de los consejos de Estado y ministros, ostenta la representación del país, y, aunque no tiene asignadas funciones como titular del Estado, si posee atribuciones como cabeza de estos cuerpos; vi) inexistencia de mecanismos de control político específicos del parlamento sobre el Consejo de Estado o el Consejo de Ministros, que desemboquen en la dimisión de sus miembros o en un juicio político; vi) imposibilidad de que el Consejo de Estado o su presidente disuelvan a la asamblea. Villabella ARMENGol, Carlos Manuel, "De Guáimaro a la Habana. Historiografía de la organización del poder en el constitucionalismo cubano”, Revista Cubana de Derecho, Núm. 32, 2009, pp. 5-32. 
De esta modificación, fue discutible el procedimiento parcial a través del cual se efectúo, cuando técnicamente debió acudirse al mecanismo agravado previsto en la cláusula de reforma, no solo por la extensión y los contenidos que abarcó, sino además, porque alcanzó una norma del capítulo de derechos fundamentales para lo que se requería técnicamente referendo. Ello se justificó oficialmente, con el argumento de que el contenido del derecho de libertad de conciencia y religión se amplió, por lo que no era necesario convocar a referendo para aprobar la reforma. 100

La enmienda del 2002 ocurrió en respuesta a las medidas agresivas que en ese año anunció el gobierno norteamericano en contra de Cuba. Fue impulsada por organizaciones sociales y respaldadas por más de 8 millones de firmas ciudadanas. Comprendió los artículos tercero y undécimo reguladores de la soberanía, el 137 relativo al procedimiento de reforma y adicionó una disposición transitoria. El propósito fue blindar al sistema político socialista. Con esa intención, lo declaró irrevocable, transformando lo que era un límite implícito de reforma (la fórmula política) en un límite sustancial. Al paralelo, eliminó la posibilidad de reforma total.

De este cambio deben destacarse los siguientes aspectos que incidieron en la ruptura constitucional que se produjo posteriormente. En primer término, afectó la cláusula de reforma que es un límite implícito de reforma porque expresa la voluntad del constituyente soberano sobre el particular y, en consecuencia, el constituyente instituido no puede modificar. En segundo orden, al eliminar la posibilidad de reforma total asentó la petrificación del texto, además de que resulta un sinsentido porque el poder soberano es metajurídico, supremo, legítimo per se, creador e incondicionado. En tercer lugar, la reforma no fue coherente en los enunciados que introdujo. El artículo tercero señaló que “(...) el socialismo y el sistema político y social revolucionario (...) es irrevocable" y el artículo 137 enunció que no podrá reformarse “(...) el sistema político, económico y social (...)" La diferencia parece nimia, pero la interpretación gramatical del último precepto limita un cambio en el sistema económico.

La ley suprema de 1976 fue igualmente mutada, aunque no existen estudios que expongan la magnitud de ese fenómeno. Ocurrieron prácticas políticas que lo complementaron (mutación tácita), se nominalizaron o desactualizaron artículos (mutación por desuetudo) y acaecieron prácticas y se emitieron normas de diferente jerarquía que, obedeciendo al cambio de circunstancias socioeconómicas, contradijeron la preceptiva constitucional (mutación sustancial). En los últimos casos la validez fue controvertible porque, en puridad, se produjo un quebrantamiento de la ley fundamental. ${ }^{101}$

La Constitución del 2019 se promulgó luego de varios años de ostensible caducidad del texto anterior. No fue concebida en asamblea constituyente como su predecesora, pero al igual que aquella, el proyecto redactado por una comisión del parlamento fue sometido a consultar popular y se aprobó por referendo.

100 Escalona RegueRA, Juan, "Sobre el proceso de perfeccionamiento de los órganos del Poder Popular”, Revista Cubana de Derecho, Núm. 11, 1995, pp. 5 y ss.

101 DAU-Lin, Hsü, Mutación de la Constitución, Instituto Vasco de Administración Pública, Oñati, 1988, pp. 31 y ss. Hesse, Konrad, Escritos de Derecho Constitucional, Centro de Estudios Constitucionales, Madrid, 1992. pp. 103 y ss. VEGA GARCíA, Pedro de, La reforma de la Constitución y la problemática del poder constituyente, Editorial Tecnos, Madrid, 2000, pp. 215 y ss. 
Según cifras oficiales, la ciudadanía realizó 1445289 intervenciones, 2100 de ellas de cubanos residentes en el extranjero, incorporándose el $40 \%$ de los planteamientos. El texto original conservaba solo 11 artículos de la carta de 1976; luego del proceso de consulta se realizaron 760 cambios a éste, reformulándose 134 artículos, eliminándose tres, añadiéndose cinco e incluyéndose dos sesiones.

Debe añadirse que, lo que se postuló inicialmente como una reforma al texto de 1976 culminó arrojando una Constitución nueva, cuestión que provocó una ruptura en la continuidad constitucional porque la Asamblea Nacional no tenía competencia para iniciar una reforma total, debido a la comentada enmienda de 2002 que suprimió esa posibilidad.

Del nuevo texto resaltan, prima facie, cuatro cualidades. En primer lugar, se alejó del modelo constitucional de 1976. Dos temas grafican esto de manera puntual: legitimó la propiedad privada sobre bienes de producción de personas naturales y jurídicas cubanas y extranjeras, al paralelo que reconoció al mercado bajo la regulación del Estado; y trasfiguró la organización del poder público al refrendar la figura del presidente como titular del Estado.

Lo anterior no implica que se variara la fórmula política. El texto ratifica el sistema politico socialista, confirma al partido comunista como ente dirigente de la sociedad y el Estado, y ratifica la irrevocabilidad del sistema socialista; punto que se enfatiza en el preámbulo, el artículo 4to y la cláusula de reforma.

Otro elemento distintivo es que se acogieron postulados y tendencias del constitucionalismo contemporáneo, verbigracia: refrendo de principios, admisión de la doble ciudadanía, reconocimiento de los diversos tipos de familia, regulación de la igualdad desde la no discriminación multidimensional principio de progresividad de los derechos, integración de los tratados al orden jurídico, etc. Resulta paradójico la exclusión de la cláusula de interpretación de los derechos acorde a los estándares de los tratados de derechos humanos, que aparecía en el proyecto que fue aprobado inicialmente por el parlamento.

Un cuarto aspecto es la gran remisión a leyes que se realiza en el texto para acotar, complementar o desarrollar diferentes enunciados, cuestión que lastra la eficacia directa de la Carta Magna. En 143 momentos el articulado plantea que "la ley fija", "la ley establece", "la ley regula", o "según lo previsto en ley". De ellos, en 50 ocasiones aproximadamente, se trata de aspectos ya normados que requeririan reformularse, los demás, son leyes que deberán promulgarse. Lo más preocupante es que algunos contenidos, por su trascendencia, deben ser cotos del constituyente; verbi gratia: las causales de la pérdida de la ciudadanía, la acción para la garantía de los derechos, los presupuestos para la interpretación de las leyes, las pautas para el ejercicio de la iniciativa y el proceso de formación legislativa.

Otras características de la Constitución son las siguientes: extenso preámbulo de matiz histórico e ideológico, la plataforma ideológica del texto se trasluce también en el título primero que regula los fundamentos políticos del régimen y se consagra la formula política; acogida de valores y principios que delinean un plexo axiológico (dignidad humana, humanismo, equidad, solidaridad, bienestar, prosperidad individual y colectiva, desarrollo integral del ser humano, no discriminación); afirmación de la supremacía constitucional; admisión de la inserción de los tratados internacionales aprobados, en el 
ordenamiento infraconstitucional; regulación de un régimen económico mixto con predominio de la propiedad estatal y bajo la dirección del Estado (participan junto a la propiedad estatal, la propiedad privada que sustenta la pequeña empresa, la propiedad privada de persona natural o jurídica extranjera y la propiedad mixta); reconocimiento del principio de igualdad como equivalencia de oportunidades, no discriminación y satisfacción de necesidades materiales básicas; positivación de un catálogo de derechos individuales, colectivos y difusos (en los derechos económicos y sociales se reconoce el basamento material para el desarrollo de las políticas públicas, mientras en algunos derechos individuales existe indefinición del contenido esencial y su configuración queda en manos del legislador); refrendo de un mecanismo estatal compuesto por la Asamblea Nacional como órgano supremo, el Consejo de Estado como ente que representa a la asamblea y funge como comisión permanente suya, el presidente como titular del ejecutivo y el consejo de ministro como institución de gobierno; configuración de una forma de gobierno mixta que reúne caracteres de diferentes sistemas; institucionalización de órganos que no tenían reconocimiento constitucional (Consejo Electoral Nacional y Contraloria General); replanteo de las dimensiones conceptuales de la provincia y los municipios (la provincia se planteó como eslabón intermedio entre el poder central y el municipio, y su órgano de gobierno como ente ejecutivo-administrativo del Estado; el municipio se reguló como la unidad politica primaria de la organización territorial, dotada de autonomía para satisfacer las necesidades locales).

Esta fuente del derecho constitucional cubano se inició con una revolución armada que marcó un antes y después en la historia nacional. La Ley Fundamental de 1959 amparó el proceso de refundación política, pero quedó rebasada por vía normativa y convencional, sobreviniendo un periodo de inconstitucionalidad y provisionalidad política. El texto de 1976 representó un parteaguas en la historia cubana al legitimar el socialismo, acogiendo los principios del sistema e ignorando el constitucionalismo precedente, en ese plano, configuró una forma de Estado semiconvencional. Su paulatina obsolescencia suscitó anomia constitucional. La Carta Magna del 2009 se distancia del canon de la ley de 1976 y del presupuesto del socialismo ortodoxo que esta refrendó, aunque ratifica la fórmula política del sistema político, asumió corrientes del neoconstitucionalismo y contornó un prototipo de gobierno mixto.

\section{CONCLUSIONES}

En el siglo XIX se asientan las bases de la España contemporánea, fue una etapa políticamente inestable, en la que progresó un constitucionalismo transaccional y un Estado que no definía su fisonomía. ${ }^{102}$ En ese contexto, la relación entre España y Cuba, como asevera Portuondo Zuñiga, fue un diálogo "entre sordos y ciegos", 103 y, los liberales españoles, no concretaron una solución politica al tema colonial: "fue una historia de paternalismo y mezquindad, de tira

102 SuAnZeS-CARPEgnA, Joaquín Varela, "La construcción del Estado en la España del siglo XIX. Una perspectiva constitucional”, en Carlos Villabella Armengol, Hitos del constitucionalismo del siglo XIX cubano. Editorial Ácana, Ediciones Universidad de Camagüey, Instituto de Ciencias Jurídicas de Puebla, Camagüey, 2009, pp. 13-25.

103 Portuondo ZÚÑIGA, Olga, Cuba. Constitución y liberalismo (1808-1841), vol. I, ob. cit., p. 75., 
y afloja, de ensayos y experimentos, convertida Cuba en laboratorio institucional y permanente problema para el que no se acabó de encontrarse solución (...)."104

En esa tesitura, el derecho español tuvo un escaso relieve práctico allende los mares. La carta de 1812 fue documento primigenio del constitucionalismo revolucionario y vía de entrada de las ideas liberales a Latinoamérica; en la Isla, tuvo impacto jurídico-institucional en sus breves períodos de vigencia y trascendencia ideológica. El texto de 1897 implementó un gobierno autonómico, fórmula a la que se aspiraba desde la segunda década de esa centuria, por ello, su implementación fue extemporánea.

En esa centuria se elaboraron diversos proyectos constitucionales que denotaron el sentir político criollo y expresaron matices de su pretensión reformista y descentralizadora. Éstos, constituyeron expresión auroral de identidad cubana y manifestaron la paulatina delimitación de la noción de patria. Los dos primeros textos se fechan en 1811, el de José Agustín y Caballero y Rodríguez de la Barrera, enuncia una línea de pensamiento liberal-reformista que anhela mayor reconocimiento político de los criollos y la instauración de un gobierno autonómico. El documento de Joaquín Infante Infante, muestra la postura liberal-radical que proyecta la separación con España, conectándose con el movimiento revolucionario del continente.

El derecho constitucional cubano lo integran tres fuentes que responden a entornos histórico-politicos diferentes. El derecho mambí de finales del siglo XIX institucionalizó la guerra independentista, nutriéndose de principios e instituciones del constitucionalismo revolucionario norteamericano y francés. E1 derecho nacional-burgués de la primera mitad del siglo XX forjó el Estado-nación que evolucionó de manera frágil y con sucesivas interrupciones democráticoinstitucionales, transitando del constitucionalismo liberal al social. El derecho revolucionario-socialista emergió de una revolución amada, sustentó el proceso de desmontaje político del régimen anterior, amparó el breve momento nacionalista-reformador que se desarrolló entre 1959 y 1961, y legitimó el sistema socialista.

El derecho mambí legitimó mecanismos de poder republicanos que condujeron la guerra y ordenaron la sociedad sobre la que se asentaban. Así, puede sostenerse que el Estado cubano se cimentó en ese periodo, a tenor de la institucionalidad y legalidad gestada por las constituciones de Guáimaro, Jimaguayú y la Yaya, y de la actividad de gobierno desplegada por el aparato de poder creado. Admitir esta tesis requiere de un enfoque holístico que rebase la percepción del Estado como ente creado de una sola vez con todos sus atributos y elementos; precisa, visualizar su construcción en la dinámica de una guerra de liberación nacional. 105

104 Alonso Romero, María Paz, Cuba en la España liberal (1837-1898). Génesis y desarrollo del régimen autonómico, ob. cit., pp. 59-60.

105 Sobre esta tesis ver: Villabella ARmengol, Carlos Manuel, "La Constitución de Guáimaro y el Estado cubano. Una opinión controvertible”, Cuadernos de historia principeña, Núm. 8, Editorial Ácana, Camagüey, 2010, pp. 52 y ss. También: "El origen del Estado en Cuba: una polémica no resuelta”, en Ana María Álvarez-Tabío Albo y Andry Matilla Correa (coords.), El Derecho público en Cuba a comienzos del siglo XXI. Homenaje al Dr. Fernando Álvarez Tabio, Editorial Universidad de la Habana, La Habana, 2011. 
De las constituciones cubanas, los textos de 1869, 1897, 1901, 1940, 1976 y 2009 implantaron cánones. El documento de Guáimaro fue la primera expresión del derecho constitucional cubano. En el transcurso de su vigencia se forjó la nacionalidad y se fundó el Estado cubano. La ley suprema de la Yaya fue, de esa fuente, la más acabada técnica y formalmente. La Constitución de 1901 simbolizó el nacimiento de la República de Cuba como Estado-nación independiente, respondió al modelo liberal de constitución que por la época cerraba un ciclo de vida. La Carta Magna de 1940 fue un documento precursor, transformador, forjador del constitucionalismo social; no tuvo completitud normativa ni fueron desplegados totalmente sus postulados progresistas mediante políticas públicas. La Constitución de 1976 refrendó el sistema político socialista que ya existía, gestándose sobre la doctrina de ese signo ideológico; fue un documento técnicamente pobre. La Carta Magna de 2009 ratifica el sistema político socialista, armonizando con doctrinas e instituciones del constitucionalismo contemporáneo; su normativa realiza una gran remisión a leyes para acotar o desarrollar contenidos.

El derecho constitucional cubano ha configurado diferentes formas de gobierno: asamblearia, convencional, presidencial, presidencial con rasgos parlamentarios, semiconvencional, mixta. Estas catalogaciones se realizan a partir del patrón existente en el derecho comparado, aunque en algunos casos no se configuren todos los rasgos. En ese sentido, puede aseverarse que una constante ha sido la configuración de tipologias "experimentales".

De igual forma, en reiteradas ocasiones se institucionalizaron organizaciones de poder centralizante: las leyes constitucionales de 1934 y 1935 concentraron la función legislativa, ejecutiva y de gobierno en el presidente y el Consejo de Secretarios; la Resolución Conjunta de 1935 creó un mecanismo de poder provisional integrado por el presidente, varios secretarios de Estado, el presidente del Consejo de Estado y el alcalde municipal de La Habana; el Estatuto Constitucional de 1952 refrendó una estructura que concentró el poder en el presidente y el Consejo de Ministros; la Ley Fundamental de 1959 normó un mecanismo similar.

El cónclave de Guáimaro diseño una asamblea con poder efectivo, ante el temor de una organización de poder personalista y autoritaria. Así lo reconoció Antonio Zambrana, uno de sus redactores. ${ }^{106}$ El Consejo de Gobierno creado en Jimaguayú y consolidado en la Yaya, fue una salida ante la necesidad de autonomía militar para la conducción de la guerra y la convicción de que el poder público debía revestir formas republicanas. Por ello, Hernández Corujo apuntó con tino que fue un aporte de la historia constitucional cubana ante la imposibilidad de repetir la inviable organización gestada en Guáimaro. ${ }^{107}$

La Constitución de 1901 reguló un modelo presidencial similar al norteamericano. La Carta Magna de 1940 diseñó un presidencialismo atenuado

106 ZambranA, Antonio, “La República de Cuba”, Cuadernos Cubanos, Núm. 3, Universidad de La Habana, La Habana, 1969, pp. 31-43.

107 HeRnández CoRujo, Enrique, Organización civil y politica de las revoluciones cubanas de 1869 y 1895, ob. cit., pp. 75, 76. 
con elementos parlamentarios, aunque autores como Andrés Lazcano, 108 Jorge de la Fuente ${ }^{109}$ y Julio Carreras, ${ }^{110}$ señalan que se consagró una forma de gobierno semiparlamentaria. Debe destacarse que el debate sobre la conveniencia de adoptar un régimen parlamentario en el país devenía de inicios de siglo. ${ }^{111}$ Quedo silenciada en la constituyente de 1901 ante el influjo del modelo norteamericano, empero, la idea tomo cuerpo explicitamente en algunas de las iniciativas de reformas escritas durante el primer cuarto de siglo. De los proyectos presentados al Congreso en esa época, los de Antonio Berenguer y Sed, Ricardo Dolz y Arango, José Manuel Cortina y Carlos Manuel de la Cruz, postularon una forma de gobierno parlamentaria; de los documentos que no se tramitaron, el de Enrique Loynaz del Castillo también abrazó tal postura.

Los redactores de la ley fundamental de 1976 siguieron el patrón del constitucionalismo socialista, institucionalizó a la asamblea nacional como órgano legislativo y supremo poder del poder, la que elegía entre sus miembos al Consejo de Estado, ente que se le subordinaba y fungía coo ejecutivo colegiado. Esta institución, ante la efimera presencia del legislativo, constituía la clave de bóveda del entramado estatal.

La Constitución de 2019 ha contornado una tipología de gobierno mixta porque reúne rasgos del parlamentarismo (ejecutivo bicéfalo nombrado por el legislativo, el presidente es jefe de Estado y el primer ministro es jefe de gobierno), el presidencialismo (facultad legislativa del presidente mediante decretos, figura del vicepresidente sin atribuciones propias), el semipresidencialismo (el titular del ejecutivo preside el consejo de ministros) y el modelo convencional (la asamblea como órgano preponderante, el jefe de estado no tiene derecho de veto sobre los proyectos de ley ni poder para disolverla).

En el derecho constitucional cubano ha sido reiterado el déficit de efectividad de las cartas magnas. Los textos mambises estuvieron limitados por las condiciones de guerra. La constitucionalidad de la primera mitad del siglo XX fue quebradiza y estuvo interrumpida por golpes de Estado y leyes emitidas por los gobernantes para legitimarse. El texto de 1901 se interrumpió en 1928, fue restablecido y depuesto con solo meses de diferencia en 1933, y retomado parcialmente por la ley provisional de 1935. La carta de 1940 fue quebrada por el golpe de Estado de 1952. La ley fundamental de 1959 jugo su rol escasamente dos años, a partir de 1961 fue sobrepasada por la realidad y su supremacía se difuminó. La Constitución de 1976 fue regla de reconocimiento durante poco más de diez años, a partir de la década del noventa fue rebasada y sobrevino un periodo de vaga supremacía constitucional.

108 LaZCANO y Masón, Andrés M., Las constituciones de Cuba, ob. cit., pp. 117 y ss.

109 Fuente, Jorge de la, Análisis constitucional desde Jimaguayú hasta el 40, ob. cit., p. 165.

110 CARreras, Julio Ángel, Historia del Estado y el Derecho en Cuba, ob. cit., pp. 484 y ss.

111 GIBERGA, Eliseo, "Conferencia pronunciada en el Ateneo de La Habana el 26 de diciembre de 1906 sobre el sistema parlamentario, en el debate sobre la forma de gobierno más conveniente en Cuba", en Obras de Eliseo Giberga. Discursos Politicos, Vol I, Imprenta y Papelería de Rambla, Bouza y Ca La Habana, 1930, pp. 342-370. Del mismo autor: "El parlamentarismo en la constitución cubana”, en Obras de Eliseo Giberga. Discursos Políticos, Vol I, Imprenta y Papelería de Rambla, Bouza y Ca La Habana, 1930, pp. 386-413. 
La Constitución de 2019, con incoherencias y ausencias, es superior en contenidos y técnica a su antecesora, regula de manera más acabada la organización estatal, se enlaza con precedentes históricos, asume corrientes del derecho moderno y el debate de su articulado suscitó culturización constitucional, factor importante en la apropiación social de una ley fundametal, o como diría Lucas Verdú, en la germinación de "sentimiento constitucional".112

\section{BIBLIOGRAFÍA}

ÁBALO, J.L., La Forma Técnico Funcional del Gobierno, Ediciones Montero, La Habana, 1939.

Aguado Renedo, César, "El primer precedente directo de los actuales Estatutos de Autonomía: las "Constituciones Autonómicas" de Cuba y Puerto Rico". Revista de Historia Constitucional, Núm. 3, 2002, pp. 249-255.

AGUIRRE, Sergio, Nacionalidad y nación en el siglo XIX cubano, Ciencias Sociales, La Habana, 1990.

Agustín Caballero, José, “Exposición a las Cortes españolas”, en Obras, Biblioteca clásicos cubanos, Imagen Contemporánea, La Habana, 1999.

Agramonte, Roberto, José Agustín Caballero y los origenes de la conciencia cubana, Universidad de La Habana, La Habana, 1952.

Alonso Romero, María Paz, “Cuba, provincia asimilada: 1878-1898”, en Derecho y Administración Pública en las Indias hispánicas (Actas del XII Congreso Internacional de Historia del Derecho Indiano), Ediciones Universidad de CastillaLa Mancha, Cuenca, vol. I, 2002.

Alonso Romero, Maria Paz, Cuba en la España liberal (1837-1898) Génesis y desarrollo del régimen autonómico, Centro de Estudio Político Constitucionales, Madrid, 2002.

Álvarez Tabío, Fernando, Evolución constitucional de Cuba (1928-1940), Talleres Gráficos O`Reilly 259, La Habana, 1953.

ARAngo y PARReño, Francisco, Obras, Publicaciones de la Dirección de Cultura del Ministerio de Educación, Tomo I y II, La Habana, 1952.

Archivo Histórico Nacional, Fondo Donativos y Remisiones, Legajo 165.

Archivo Histórico Nacional, Periódico "La República”, Núm. 7, Camagüey, 1ro de julio de 1876 , año $1^{\circ}$.

Archivo Nacional de Cuba, Fondo Gobierno Civil. Noticias de las principales ocurrencias acaecidas en La Habana el dia 15 de abril de 1820 y siguientes remitidas por el Intendente de Ejército al Secretario del Estado y el Despacho.

Bachiller y Morales, Antonio, Apuntes para la historia de las letras y de la instrucción pública en la isla de Cuba, Cultural, S. A., La Habana, vol. III, 1937.

112 LuCAS Verdú, Pablo, El sentimiento constitucional. Aproximación al estudio del sentir constitucional como modo de integración política, Madrid, Editorial Reus, 1985. 
Bahamonde Rodríguez, Santiago y Mulet Martínez, Fabricio, "Jimaguayú. Apuntes de Historia Constitucional cubana", Revista de Historia del Derecho, Núm. 54, julio-diciembre 2017, pp. 11 y ss.

BARcia, María del Carmen; García, Gloria; Torres Cueva, Eduardo, Historia de la colonia, evolución socioeconómica y formación nacional, desde los origenes hasta 1867, Editora Política, La Habana, 1994.

BELKIN, Jack M. Y LEVINSON, Sanford, "Los cánones en el derecho constitucional", en Miguel Carbonell y Leonardo García Jaramillo (eds.), El canon constitucional del neoconstitucionalismo, Instituto de Investigaciones Jurídicas, UNAM-Editorial Trotta, México, 2010.

BERnAL Gómez, Beatriz, "El primer proyecto de constitución independentista para Cuba", en Estudios juridicos en homenaje a María Morineau, vol. I, Instituto de Investigaciones Jurídicas, UNAM, México, 2006.

Bernal Gómez, Beatriz, Constituciones Iberoamericanas: Cuba, Instituto de Investigaciones jurídicas, UNAM, México, 2008.

BiscaretTI DI Ruffia, Paolo, Introducción al Derecho Constitucional Comparado, 2da edición, Fondo de Cultura Económica, México, 2000.

BizCARrondo, Marta y Elorza, Antonio, Cuba/España. El dilema autonomista, 1878-1898, Editorial Colibri, Madrid, 2001.

Borges, Milos A., Compilación ordenada y completa de la legislación cubana (1899-1859). Índice Alfabético, 2da. ed., Editorial LEX, La Habana,1952.

Cantón Navarro, José; Zanetti Lecuona, Oscar; Álvarez-Tabio Longa, Pedro; et. al., Historia de Cuba. La neocolonia. Organización y crisis desde 1899 hasta 1940, Editorial Félix Varela, La Habana, 2004.

CARRERA JÚSTIZ, Francisco, Introducción a la historia de las instituciones locales de Cuba, vol. II, Librería e Imprenta La Moderna Poesía, La Habana, 1905.

CARreras, Julio Ángel, Historia del Estado y el Derecho en Cuba, Editorial Pueblo y Educación, La Habana, 1982.

Carrillo y Arango, Anastasio, Obras del excelentísimo Sr. Arango y Parreño, vol. I y II, Imprenta Manuel Galiano, Madrid, 1869.

CAsasús, Juan J., La Nueva Ciudad del Sol, Cultural S.A., La Habana, 1937.

"Constitución de Guáimaro", en LAzCANO Y MAZÓn, Andrés M., Las Constituciones de Cuba, Ediciones Cultura Hispánica, Madrid, 1952.

"Constitución de Jimaguayú", en LAzCANo y Mazón, Andrés M., Las Constituciones de Cuba, Ediciones Cultura Hispánica, Madrid, 1952.

Cruz Villalón, Pedro; Lorente Sariñena, Marta; et. al., Los orígenes del constitucionalismo liberal en España e Iberoamérica: Un estudio comparado, Junta de Andalucía/Consejería de Cultura y Medio Ambiente, Sevilla, 1994.

Dau-Lin, Hsü, Mutación de la Constitución, Instituto Vasco de Administración Pública, Oñati, 1988.

"Dictamen de las Comisiones reunidas de Ultramar y Constitución,10 de febrero de 1837, proponiendo que las provincias ultramarinas de América y Asia 
EL DERECHO CONSTITUCIONAL CUBANO DE 1812 AL 2009: CÁNONES, ...

sean regidas y administradas por leyes especiales”, Apéndice al DSC, No. 112, de 12

Fuente, Jorge de la, Análisis constitucional desde Jimaguayú hasta el 40, Editorial Ciencias Sociales, La Habana, 1989.

Dolz Y ARANGO, Ricardo, "Proyecto presentado por el senador Ricardo Dolz", en La Reforma social, vol. X, Núm. 3, Casa Editorial La Reforma, Nueva York, 1918.

EnTRAlGo, Elias, Los diputados por Cuba en las Cortes de España durante los tres primeros periodos constitucionales, Academia de Historia de Cuba, Editorial Siglo XX, La Habana, 1945.

ESCALONA REgueRA, Juan, "Sobre el proceso de perfeccionamiento de los órganos del Poder Popular", Revista Cubana de Derecho, Núm. 11, 1995, pp. 5 y ss.

Expediente sobre el proyecto de reforma de nuestra Constitución politica escrito por D. Gabriel Claudio de Sequeira, vecino de Matanzas. ANC, Fondo Asuntos Políticos, 1822, Leg. 20, Exp.94-95

Fernández Bulté, Julio, Historia del Estado y el Derecho en Cuba, Editorial Félix Varela, La Habana, 2005, pp. 66 y ss.

FERnÁNDEZ SARASOla, Ignacio, "La Constitución de 1812 y su proyección europea, e iberoamericana", Fundamentos, Cuadernos monográficos de teoría del Estado, derecho público e historia constitucional, Núm. 2, 2000, pp. 359-457.

Fernández SARAzola, Ignacio, Proyectos constitucionales de España (17861824), Centro de Estudios Político Constitucionales, Madrid, 2004.

FERRARA, Orestes, "La reforma constitucional en Cuba", en La Reforma social, vol. X, Núm. 2, Casa Editorial La Reforma, Nueva York, 1918.

FERRARA, Orestes, Las ideas juridico-sociales en las constituciones cubanas, conferencia pronunciada en el ilustre Colegio de Abogados de Madrid el 29 de enero de 1945, Talleres Gráficos Marsiega, Madrid, 1945, p. 26.

FiX-Zamudio, Héctor y Valencia Carmona, Salvador, Derecho Constitucional Mexicano y Comprado, UNAM, Editorial Porrúa, México, 2001.

Folleto de Divulgación Legislativa. Proclamas y Leyes del Gobierno Provisional de la Revolución, Núm. 1, Editorial LEX, La Habana, 1959.

FrAnCo PÉRez, Antonio-Filiu, "Cuba y el orden jurídico español del siglo XIX: La descentralización colonial como estrategia y táctica jurídico-politica (1837-1898)", Revista de Historia constitucional, Núm. 5, 2002.

FRANCO PÉREZ; Antonio-Filiú, "Vae victisi, o biografía politica del autonomismo cubano (1878-1898)", Revista de Historia Constitucional, Núm. 3, 2002, pp. 257279.

FrANCO PÉREZ; Antonio-Filiú, Cuba en los orígenes del constitucionalismo español: la alternativa descentralizadora (1801-1837), Fundación Manual Gimenez Abad de Estudios Parlamentarios y del Estado Autonómico, Zaragoza, 2011.

GARCÍA MorA, Luis Miguel, "La fuerza de la palabra. El autonomismo en Cuba en el último tercio del siglo XIX”, Revista de Indias, vol. LXI, Núm. 223, pp. 715- 
748. TORRE, Mildred de la, El autonomismo en Cuba, 1878-1898, Editorial Ciencias Sociales, La Habana, 1997.

GARCÍA RodRÍGUez, Gloria, "Estudio introductorio", en Francisco de Arango y Parreño, Obras, Biblioteca Clásicos cubanos, vol. I, Imagen Contemporánea, La Habana, 2005.

GARCINI Guerra, Héctor, "La Constitución del Estado Socialista”, Revista Cubana de Derecho, Núm. 12, 1976, p. 25 y ss.

Gay-GalBó, Enrique, Nuestro Problema Constitucional, Librería Nueva, La Habana, 1936.

GIBERGA, Eliseo, "Conferencia pronunciada en el Ateneo de La Habana el 26 de diciembre de 1906 sobre el sistema parlamentario, en el debate sobre la forma de gobierno más conveniente en Cuba", en Obras de Eliseo Giberga. Discursos Politicos, vol. I, Imprenta y Papelería de Rambla, Bouza y Ca, La Habana, 1930.

GIBERGA, Eliseo, "El parlamentarismo en la constitución cubana”, en Obras de Eliseo Giberga. Discursos Politicos, vol. I, Imprenta y Papelería de Rambla, Bouza y Ca, La Habana, 1930.

Guerra Y SÁnchez, Ramiro; Pérez CABrera, José; Remos, Juan J.; Santovenia, Emeterio S., Historia de la Nación Cubana, vol. I-X, Editorial Historia de la Nación Cubana, S. A., La Habana, 1952.

Guerra, Ramiro, Guerra de los 10 años, vol. I y II, Editorial Ciencias Sociales, La Habana, 1972.

Gutiérrez y SÁnchez, Gustavo, Historia del Derecho Constitucional cubano, Cultura S. A., La Habana, 1938.

HERnÁNDEZ CORUJO, Enrique, Organización civil y politica de las revoluciones cubanas de 1869 y 1895, Imprenta y Papelería de Rambla y Bouza, La Habana, 1929.

Hernández Corujo, Enrique, "Significación y proyecciones de la Constitución de Guáimaro" Anuario de la Facultad de Ciencias Sociales y Derecho Público, , Universidad de La Habana, Editora LEX, La Habana, 1950.

HERNÁNDEZ CORUJo, Enrique, "Militarismo y Civilismo en las Constituciones de Cuba en Armas”, en Revista Cubana de Derecho, Año XXI (Nueva Serie), Núm. IV (84), octubre-diciembre de 1946.

HERnÁNDEZ CORUJO, Enrique, Fundamentos históricos y filosóficos sobre la Constitución de 1901, Editora LEX, La Habana, 1953.

HeRnÁndez Corujo, Enrique, Historia constitucional de Cuba, Compañía editora de libros y folletos, La Habana, 1960. Vol. I.

Hernández Travieso, Antonio, El padre Varela. Biografía del forjador de la conciencia cubana, 2da. edición, Ediciones Universal, La Habana, 1984.

Hesse, Konrad, Escritos de Derecho Constitucional, Centro de Estudios Constitucionales, Madrid, 1992.

IBARRA CUESTA, Jorge, Varela, el precursor. Un estudio de época, Editorial Ciencias Sociales, La Habana, 2008. 
INFIESTA Y PAGES, Ramón, El autonomismo cubano; su razón y manera, Jesús Montero Editor, La Habana, 1939.

Infante, Joaquín, Proyecto de Constitución para la Isla de Cuba., Academia Nacional de Historia, Ediciones Guadarrama, Venezuela, 1954.

InfIESTA y PAGes, Ramón, Derecho Constitucional, 2da ed. Editorial LEX, La Habana, 1954.

"Indicación que hizo D. Gabriel Claudio de Sequeira en la sesión que tuvo la Comisión del Ayuntamiento de la Ciudad de Matanzas para instrucciones de Diputados a Cortes por esta provincia, el 1ro de abril de 1822", en Expediente sobre el proyecto de reforma de nuestra Constitución politica escrito por D. Gabriel Claudio de Sequeira, vecino de Matanzas. ANC, Fondo Asuntos Políticos, 1822, folios 8-9, $16-18,21$.

LASA, José Maria, Projecto presentando por el representante José María Lasa, en La Reforma Social, vol. X, Núm. 3, Casa Editorial La Reforma, Nueva York, 1918.

Lazcano y Masón, Andrés M., Las Constituciones de Cuba, Ediciones Cultura Hispánica, Madrid, 1952.

LARA HERNÁNDEZ, Eduardo. Nuestra Constitución, algunas consideraciones sobre sus fundamentos teóricos y sus raices históricas, Colección de Estudios Jurídicos, La Habana, 1983.

LeIVA LAJARA, Edelberto, "Estudio introductorio", en José Agustín Caballero, Obras, Biblioteca Clásicos cubanos, Imagen Contemporánea, La Habana, 1999.

"Ley Constitucional de 1934", en Las Constituciones de Cuba, Ediciones Cultura Hispánica, Madrid, 1952.

"Ley de Reforma Agraria", en Folletos de Divulgación Legislativa. Leyes del Gobierno Provisional de la Revolución, Núm. VIII, Editorial LEX, La Habana, 1959.

Mañas, Arturo, La Convención Constituyente del Artículo 115, Imprenta F. Verdugo, La Habana, 1928.

LlaVerias, Joaquín y SANTOVEnia, Emeterio, Actas de las Asambleas de Representantes y del Consejo de Gobierno durante la guerra de independencia (1897-1898), Academia de la Historia de Cuba, vol. II, Imprenta El Siglo XX, La Habana, MCMXXX.

Loynaz del Castillo, Enrique, Proyecto de Constitución para la República de Cuba, Talleres Tipográficos de "La Tribuna", San José de Costa Rica, 1935.

Luz y Caballero, José de la, "El Presbitero Don José Agustín Caballero", vol. III, Revista de Cuba, La Habana, 1878.

MARTí, José, Obras Completas, vol. I, Editorial Ciencias Sociales, La Habana, 1991.

MARTIRÉ, Eduardo, Proyección del liberalismo gaditano en los paises de América, Las Cortes de Castilla y León (1188-1988), Cortes de Castilla y León, Valladolid, 1990. 
Matilla Correa, Andry (Comp.), El proyecto de Constitución para la Isla de Cuba de Joaquín Infante. Aproximaciones histórico-jurídicas a propósito de su bicentenario, Universidad de La Habana, La Habana, 2012.

Matilla Correa, Andry y Massó Garrote, Marcos Francisco (Coords.), De Cádiz (1812) a La Habana, Estudios con motivo del bicentenario de la Constitución española de 1812, Unión Nacional de Juristas de Cuba, Universidad de la Habana, Universidad de Castilla La Mancha, La Habana, 2012.

Mañas, Arturo, La Convención Constituyente del Artículo 115, Imprenta F. Verdugo, La Habana, 1928

MAÑAS, Arturo, Sobre una reforma de la constitución cubana, Imprenta F. Verdugo, La Habana, 1931.

Mulet Martínez, Fabricio, "Aproximación al pensamiento jurídicoconstitucional cubano durante los años 1933-1939. El tránsito hacia un nuevo orden constitucional”, en Andry Matilla Correa, Osvaldo M. Álvarez Torres, Isnel Martínez Montenegro, Temas de Historia del Derecho y Derecho Agrario. Homenaje al profesor Orestes Hernández Más, Facultad de Derecho Universidad de La Habana, UNIJURIS, La Habana, 2013.

Mulet Martínez, Fabricio, "El desarrollo constitucional de Cuba, durante los años 1933-1939”, Revista Cubana de Derecho, Núm. 54, julio-diciembre 2017, pp. $71-101$.

Mulet Martínez, Fabricio, Entre la crisis y la reforma. Itinerario del constitucionalismo cubano (1906-1933), Pensamiento Constitucional, Núm. 2, 2017, pp. 143-173.

Noticias de las principales ocurrencias acaecidas en La Habana el dia 15 de abril de 1820 y siguientes remitidas por el Intendente de Ejército al Secretario del Estado y el Despacho, Archivo Nacional de Cuba, Fondo del Gobierno Civil.

OrTiz, Fernando, Nuevo catauro de cubanismos, Ciencias Sociales, La Habana, 1974.

Pantoja Morán, David y García Laguardia, Jorge Mario, Tres documentos constitucionales en la América Española preindependiente, Instituto de Investigaciones Jurídicas, UNAM, México, 1975.

PÉrez De la Riva, Juan; ZANetti, Oscar; López Segrera, Francisco, et. al., La república neocolonial, anuario de estudios cubanos, vol. I, II, Editorial Ciencias Sociales, La Habana, 1973.

PÉrez Guilhou, Dardo. La opinión pública española y las cortes de Cádiz frente a la emancipación hispanoamericana. 1808-1814, Academia Nacional de la Historia, Buenos Aires, 1981.

Pezuela, Jacobo de la, Historia de la Isla de Cuba, vols. I-IV, Librería Extranjera y Nacional, Científica y Literaria, Madrid, 1878.

PichaRdo, Hortensia, Documentos para la historia de Cuba, vol. I, Editorial Ciencias Sociales, La Habana, 1971.

Portuondo y DE CASTRo, José, Proyecto de Constitución, Editorial Alberto Solo, La Habana, 1934. 
PoRTUONDO, Fernando, "La cultura entre los mambises del 68", en Estudios de historia de Cuba, Editorial Ciencias Sociales, La Habana, 1986.

Portuondo Zuñiga, Olga, Cuba. Constitución y liberalismo (1808-1841), vols. I y II, Editorial Oriente, Santiago de Cuba, 2008,

Ponte Domínguez, Francisco J., Historia de la Guerra de los 10 Años, Imprenta El Siglo XX, La Habana, 1958.

Primer Índice Anual de la legislación Revolucionaria 1ro de enero a 31 de Diciembre de 1959, Editorial LEX, La Habana, 1959.

PRo RuIz, Juan, El Estatuto Real y la Constitución de 1837, IUSTEL, Madrid, 2010.

Reforma de la Constitución aprobada por el Congreso y aceptada por los delegados del pueblo de Cuba en Convención Constituyente, Gaceta Oficial de la República, Edición Extraordinaria Núm, 6, 11 de mayo de 1928.

República de Cuba, Senado, Proposición de Ley del Dr. Antonio Berenguer y Sed, sobre la revisión constitucional, presentada al Senado en sesión del 12 de agosto de 1912, Imprenta y Librería "La Moderna Poesía”, La Habana, 1912.

Reyes FERnÁndez, Eusebio, Félix Varela, 1788-1853, Editora Política, La Habana, 1989.

Rieu-Millan, Marie Laurie, Los diputados americanos en las Cortes de Cádiz (igualdad e independencia), Biblioteca de Historia de América, Consejo Superior de Investigaciones Científica, Madrid, 1990.

Rodríguez Morini, César, Anteproyecto de Constitución Politica, Económica y Social, Cultural S. A., La Habana, 1933.

Roig De Leuchsenring, Emilio, Historia de la Enmienda Platt, La Habana, Instituto Cubano del Libro, 1961.

Roig DE Leuchsenring, Emilio, Los Estados Unidos contra Cuba libre, Editorial Oriente, Santiago de Cuba, 1982.

RoIG DE LEUCHSENRING, Emilio, Los grandes movimientos politicos cubanos en la república: injerencia, reacción, nacionalismo, Molina y Cia., La Habana, 1943.

RUBIO LEGRÁ, Ángel F., El proceso de institucionalización de la revolución cubana, Editorial Ciencias Sociales, La Habana, 1985.

SÁNCHEZ ANDRÉs, Agustín, "La búsqueda de un nuevo modelo de relaciones con los territorios ultramarinos durante el Trienio Liberal (1820-1823)", Revista de Indias, Núm. 210, 1997, pp. 451-474.

SÁnchez-ARCIlla Bernal, José, Historia de las instituciones politicoadministrativas contemporáneas (1808-1975), Dykinson, Madrid, 1994.

Segundo Índice Anual de la legislación Revolucionaria 1ro de enero a 31 de Diciembre de 1960Editorial LEX, La Habana, 1960.

SuAnZES-CARPAgenA, Joaquín Varela, La Teoría del Estado en los origenes del constitucionalismo hispáno (Las Cortes de Cádiz), Centro de Estudios Constitucionales, Madrid, 1983.

SuANZES-CARPEGNA, Joaquín Varela, "La construcción del Estado en la España del siglo XIX. Una perspectiva constitucional”, en Carlos Villabella Armengol, Hitos 
del constitucionalismo del siglo XIX cubano. Editorial Ácana, Ediciones Universidad de Camagüey, Instituto de Ciencias Jurídicas de Puebla, Camagüey, 2009.

SuARez SuARez, Reinaldo, "Repercusiones de la Constitución de Cádiz en Cuba (1812-1814)", en Carlos Villabella Armengol, Hitos constitucionales del siglo XIX cubano, Editorial Ácana, Camagüey, 2011.

SuARez SuArez, Reynaldo, "Anticipándose a Cádiz: el Proyecto Constitucional para la Isla de Cuba de Joaquin Infantes", en Andry Matilla Correa y Marcos F. Massó Garrote (comp.), De Cádiz (1812) a La Habana (2012). Escritos con motivo del bicentenario de la constitución española de 1812, ONBC, UNJC, Universidad de La Habana, Universidad de Castilla-La Mancha, La Habana, 2011.

TABARES DEL ReAL, José A., Apuntes para la historia del Neocolonialismo en Cuba, DES, La Habana, 1988

TABAREs Del Real, José A., La Revolución del 30. Sus dos últimos años, Editorial Ciencias Sociales, La Habana, 1975

Tercer Índice Anual de la legislación Revolucionaria 1ro de enero a 31 de Diciembre de 1961, Editorial LEX, La Habana, 1961. El Cuarto Índice Anual de la legislación evolucionaria 1 ro de enero a 31 de Diciembre de 1964, Editorial LEX, La Habana, 1964.

Tomás y Valiente, Francisco, Manual de Historia del Derecho Español, Editorial Tecnos, Madrid, 2005.

Torres Cuevas, Eduardo, Félix Varela: los origenes de la ciencia y con-ciencia cubanas, Editorial Ciencias Sociales, La Habana, 1995.

Torres Cuevas, Eduardo; García Rodríguez, Mercedes; Ibarra Cuesta, Jorge, Félix Varela: Obras, vols. I y II, Editorial Imagen Contemporánea, La Habana, 1997,

TORRes-Cuevas, Eduardo, Historia del pensamiento cubano, vol. I, Editorial Ciencias Sociales, La Habana, 2006.

VARela Morales, Félix, "Discurso inaugural", en Escritos politicos, Editorial Ciencias Sociales, La Habana, 1977.

Varela Morales, Félix, Proyecto de Instrucción para el gobierno económicopolitico de las provincias de Ultramar, Imprenta de Tomás Albán y Cia., Madrid, 1823.

VAREla SuAnzes-CARPagena, Joaquín, La Teoría del Estado en los origenes del constitucionalismo hispano (Las Cortes de Cádiz), Centro de Estudios Políticos y Constitucionales, Madrid, 1983.

VAREla SuAnZes-CARPEgna, Joaquín "La construcción del Estado en la España del siglo XIX. Una perspectiva constitucional”, en Carlos Villabella Armengol, Hitos del constitucionalismo del siglo XIX cubano. Editorial Ácana, Ediciones Universidad de Camagüey, Instituto de Ciencias Jurídicas de Puebla, Camagüey, 2009.

Varela Suanzes-Carpegna, Joaquín, Politica y Constitución en España (18081978), $2^{\mathrm{a}}$ ed., Centro de Estudios Políticos y Constitucionales, Madrid, 2014.

VAREla SuAnzez-CARPEgna, Joaquín, "La Constitución española de 1837: una constitución transaccional”, Revista de Derecho Político, UNED, Núm. 20, invierno, 1983-1984, pp. 95-106. 
VARela SuAnzez-CARPEgna, Joaquín, "Proyectos constitucionales en España", Revista Española de Derecho Constitucional, Núm. 76, Enero-Abril, 2006, pp. 297-304.

VÁzquez Cienfuegos, Sigfrido y Amores Carredano, Juan B., "En legitima representación: los firmantes del fallido proyecto de Junta de La Habana en 1808”, Anuario de Estudios Americanos, vol. 68, Núm. 1, 2011.

Vega García, Pedro De, La reforma de la Constitución y la problemática del poder constituyente, Editorial Tecnos, Madrid, 2000.

VeGA VEGA, Juan, Derecho constitucional revolucionario en Cuba, Editorial Pueblo y Educación, La Habana, 1982.

Vergottini, Giuseppe de, Derecho Constitucional Comparado, Espasa-Calpe, Madrid, 1983.

Villabella Armengol, Carlos Manuel y Matilla Correa, Andry, Guáimaro, Alborada en la historia constitucional cubana, Ediciones Universidad, Camagüey, 2009.

Villabella Armengol, Carlos Manuel, "De Guáimaro a la Habana. Historiografia de la organización del poder en el constitucionalismo cubano", Revista Cubana de Derecho, Núm. 32, 2009, pp. 5-32.

Villabella Armengol, Carlos Manuel, "El origen del Estado en Cuba: una polémica no resuelta”, en Ana María Álvarez-Tabío Albo y Andry Matilla Correa (coords.), El Derecho público en Cuba a comienzos del siglo XXI. Homenaje al Dr. Fernando Álvarez Tabio, Editorial Universidad de la Habana, La Habana, 2011.

Villabella Armengol, Carlos Manuel: Historia constitucional y poder politico en Cuba, Editorial Ácana, Camagüey, 2009. "De Guáimaro a La Habana: historiografía del poder político en Cuba desde una perspectiva constitucional", Revista Cubana de Derecho, Núm. 32, Julio-Diciembre 2009, pp. 5-32.

Villabella ARMengol, Carlos Manuel, "Una nueva mirada al constitucionalismo cubano desde los modelos constitucionales y la periodización de la República”, Revista Cubana de Derecho, Núm. 44, Julio-Diciembre, 2014, pp. $19-53$.

Vitier, Cintio, Eso sol del mundo moral, Ediciones UNIÓN, La Habana, 1999.

VIVANCO, Jose Clemente, Constitución de la República Comentada, Imprenta y Encuadernación San Ignacio No. 58, La Habana, 1902.

YGlesia MARTínez, Teresita, Cuba, primera República, segunda ocupación, Editorial Ciencias Sociales, La Habana, 1976.

ZALDIVAR ABAD, Martha Loyda, "El obispo Espada: génesis del sentimiento constitucional por Cádiz en Cuba”, en Andry Matilla Correa y Marcos F. Massó Garrote (comp.), De Cádiz (1812) a La Habana (2012). Escritos con motivo del bicentenario de la constitución española de 1812, ONBC, UNJC, Universidad de La Habana, Universidad de Castilla-La Mancha, La Habana, 2011.

Zambrana, Antonio, "La República de Cuba”, Cuadernos Cubanos, Núm. 3, Universidad de La Habana, La Habana, 1969, pp. 31-43.

ZAmorA, Juan Clemente, "Historia de una Cátedra", Anuario de la Facultad de Ciencias Sociales y Derecho Público, La Habana, 1954, pp. 9-17. 
ZARAGOZA, Justo, Las insurrecciones en Cuba. Apuntes para la historia politica de esta isla en el presente siglo, vol. I, Imprenta de Manuel G. Hernández, Madrid, 1872 .

Fecha de envío / Submission date: 12/09/2018

Fecha de aceptación / Acceptance date: 12/02/2019 